This is the final peer-reviewed accepted manuscript of:

Cantonati M.; Stevens L. E.; Segadelli S.; Springer A. E.; Goldscheider N.; Celico F.; Filippini M.; Ogata K.; Gargini A.: Ecohydrogeology: The interdisciplinary convergence needed to improve the study and stewardship of springs and other groundwater-dependent habitats, biota, and ecosystems. Ecological indicators. 110. 1470-160X. DOI: 10.1016/j.ecolind.2019.105803

The final published version is available online at:

http://dx.doi.org/10.1016/i.ecolind.2019.105803

Rights / License:

The terms and conditions for the reuse of this version of the manuscript are specified in the publishing policy. For all terms of use and more information see the publisher's website.

This item was downloaded from IRIS Università di Bologna (https://cris.unibo.it/)

When citing, please refer to the published version. 


\title{
Ecohydrogeology: The interdisciplinary convergence needed to improve the study and stewardship of springs and other groundwater-dependent habitats, biota, and ecosystems
}

\author{
Marco Cantonati ${ }^{\mathrm{a}, *}$, Lawrence E. Stevens ${ }^{\mathrm{b}}$, Stefano Segadelli ${ }^{\mathrm{c}}$, Abraham E. Springer ${ }^{\mathrm{d}}$, \\ Nico Goldscheidere, Fulvio Celico ${ }^{\mathrm{f}}$, Maria Filippini ${ }^{\mathrm{g}}$, Kei Ogata ${ }^{\mathrm{h}}$, Alessandro Gargini ${ }^{\mathrm{g}}$ \\ ${ }^{a}$ MUSE - Museo delle Scienze, Limnology \& Phycology Section, Corso del Lavoro e della Scienza 3, I-38123 Trento, Italy

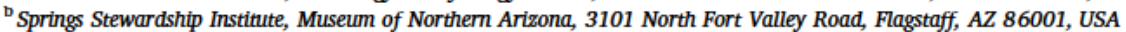 \\ ${ }^{\mathrm{c}}$ Emilia-Romagna Region, Geologic, Seismic and Soil Survey, viale della Fiera, 8, 40127 Bologna, Italy \\ ${ }^{a}$ Northern Arizona University, School of Earth and Sustainability, 625 Knoles Dr., Flagstaff, AZ 86011, USA \\ ${ }^{\mathrm{e}}$ Karlsruhe Institute of Technology (KIT), Institute of Applied Geosciences (AGW), Division of Hydrogeology. Kaiserstr. 12, 76131 Karlsruhe, Germany ${ }^{\mathrm{f}}$ \\ University of Parma, Dipartimento di Scienze Chimiche, della Vita e della Sostenibilitd̀ Ambientale, Parco Area delle Scienze 11/a, 43124 Parma, Italy ${ }^{8}$ \\ Alma Mater Studiorum University of Bologna, Department of Biological, Geological and Environmental Sciences, Via Zamboni, 67, 40126 Bologna, Italy ${ }^{\mathrm{h}}$ \\ Vrije Universiteit Amsterdam, Faculty of Science, De Boelelaan 1085, 1081 HV Amsterdam, The Netherlands
}

\section{A R T I C L E I N F O}

\section{Keywords:}

Ecohydrogeology

Ecosystem ecology

Freshwater

Hydrogeology

Groundwater-dependent ecosystem (GDE)

Groundwater-surface water interaction

Management

Policy

\begin{abstract}
A B S T R A C T
This essay discusses the need for, advantages and challenges of integrating the scientific disciplines of ecology and hydrogeology in the study of groundwater-dependent ecosystems (GDEs). We provide a definition for ecohydrogeology as "a unifying, synthetic field of study integrating the approaches from the ecological and hydrogeological sciences in the study of groundwater (GW)-related ecosystems, habitats, and organisms to advance science, stewardship, and policy". We selected specific case studies to illustrate first how hydrogeological approaches can favour in-depth understanding and modelling of springs and crenobiontic (spring-dependent) species distribution, assemblage composition and organization. Second, this essay also examines how taxa and assemblages serve as bioassays and ecosystem indicators to infer hydrogeological aspects of GW flow and discharge, as well as quantitative and qualitative human impacts. We consider both types of features and parameters as ecohydrogeological indicators. The examples presented include topics related to springs and other GDE geomorphological types and classification, GW quality influences on crenobiont distribution, phreatophyte (= plant species the roots of which reach to and into the water table) ecophysiology in relation to water table depth, and flow variability in karstic systems, to nutrient dynamics in relation to dinoflagellate blooms in GDE montane lakes. Conceptual approaches that integrate ecology with hydrogeology include the investigation of GDE distribution and ecology, groundwater-surface water (GW-SW) interactions, and the development of the discipline of ecohydrology. Despite widespread applications, the scientific community still lacks a complete or effective integration of the principles described in the fields of groundwater hydrogeology with ecology, ecophysiology, and environmental biology. Springs are aquatic-wetland-riparian habitats that link shallow subsurface-surface processes and assemblages, often functioning as biodiversity hotspots, ecotones, keystone, and refugial ecosystems, for which coordination between studies of hydrogeology and ecology are both obvious and essential. Over the past century, springs ecosystem ecology has been largely ignored by hydrologists, and, conversely, hydrogeology has been under-emphasized by ecologists. Recent global recognition of the extraordinary biodiversity and socio-cultural significance of springs, coupled with their globally highly threatened conservation status, stimulated this inquiry into how to better integrate hydrogeology with springs ecosystem ecology. Acknowledging the highly threatened status of springs ecosystems around the world, there is an urgent need to integrate and invigorate the union of these disciplines into ecohydrogeology, the study of groundwater-dependent organisms, habitats, ecosystems, and management policy.
\end{abstract}

\footnotetext{
* Corresponding author.

E-mail address: marco.cantonati@muse.it (M.

Cantonati).
} 


\section{Introduction}

Fresh water represents only $2.5 \%$ of the Earth's water volume, but approximately two thirds of that fresh water is stored as glacial or permafrost ice (e.g., Oki and Kanae, 2006). Groundwater (GW) represents $96.3 \%$ of the unfrozen global fresh water (Downing, 2014; Stevens et al., 2019a). GW-sourced ecosystems provide goods and services that have enormous ecological and socio-economic value, such as purification of water, degradation of contaminants, nutrient recycling, mitigation of floods and droughts, and refugia for many species, including early human ancestors (Griebler and Avramov, 2015; Cuthbert and Ashley, 2014; Mueller et al., 2017). Modern humans have now appropriated more than half of the renewable and accessible freshwater flows on Earth for the purposes of urban, agricultural, industrial uses (Postel et al., 1996), but nearly $80 \%$ of the world population suffers from highly threatened water security (Vörösmarty et al., 2010). Although springs are the ecosystem on which the science of ecosystem ecology was founded (Odum, 1957), and though most subsequent research on springs ecology identifies dire anthropogenic threats to natural and human-dominated groundwater-dependent ecosystems (GDEs), springs have been widely neglected in research and targeted conservation studies (e.g., Baron et al., 2002).

The Anthropocene epoch heralds humanity's overwhelming influence on planetary ecology, and we face new levels of regional, national, and global concern over freshwater availability (e.g., Rockström et al., 2014). Springs, streams, rivers, and lakes are among the most heavily modified GDEs on Earth, with primary alterations through changes in land use and climate influencing water feature morphology, hydrology, and ecosystem ecology (e.g., Carpenter et al., 2011). Climate change is predicted to affect all aspects of freshwater ecosystems because altered temperature and precipitation patterns influence geomorphology, infiltration, flow, flood intensity, sedimentation, nutrient dynamics, and detoxification, as well as ecosystem characteristics, structure, and function (Carpenter et al., 2011). To protect the world's freshwater resources, human and biodiversity perspectives on water security need to be considered jointly (Vörösmarty et al., 2010). Growing recognition of the need to preserve freshwater GDE integrity, functionality, and biological complexity has stimulated initiatives for safeguarding the many services and benefits freshwater ecosystems provide to society (e.g., Baron et al., 2002; Kreamer et al., 2015).

Satisfying the demand for balance between ecological sustainability with a global population of nine billion people by 2050 (Rockström et al., 2014) requires new approaches in the use and management of freshwater resources (Postel, 2000). A shift in conceptualization and practice is required, acknowledging the central role of water in ecosystems and societal integrity. Emphasis is needed to managing water for social-ecological resilience and sustainability (Rockström et al., 2014). Freshwater ecosystem integrity depends on adequate quantity, quality, timing, and temporal variability of flow within a natural range of variation (e.g., Baron et al., 2002). Thus, there is urgent need to develop basic understanding, technology, and policy to maintain and preserve related ecosystem services. Mitigation and restoration efforts must be based on well-grounded understanding of both hydrogeological and ecological principles (Baron et al., 2002; Carpenter et al., 2011).

Among the factors contributing to good GW policy and management, Alley et al. (2016) list the following: recognizing surface water and GW as a single resource; public education on GW and its importance; consideration of GW role within other policy areas, such as agriculture, energy, and land use; adequate laws and enforcement; fully funded and properly staffed GW management agencies; characterization of major aquifer systems; effective and independent monitoring of GW status and trends; recognizing the long-term response of GW systems; and accounting for interactions between GW and climate. However, such recognition is rare to non-existent among both developed and developing nations, and few are sustainably managing their GW supplies.
Ecohydrology integrates GDE ecological and hydrological disciplines. Over the past century, studies have been focused at the basin and sub-basin scale, as well as on applied issues, such as ecosystem remediation and improvement of resilience (Zalewski et al., 1997; Rodríguez-Iturbe, 2000; Zalewski, 2002; Cartwright et al., 2019). The intensity of interest in the intersection of hydrogeology and ecology has led to the publication of several specialised journals, including Ecohydrology and Ecohydrology \& Hydrobiology. Another result of this integration has been the conceptualization and practice of environmental flow management, as evidenced by Mott LaCroix et al. (2017).

Several specific areas of hydrogeological study remain under-integrated with GDE ecology research. The term groundwater-dependent ecosystem is widely used and refers to the linkage between aquifers and associated subterranean and surface water bodies, relationships that require a more fully integrated, multidisciplinary research (e.g., Eamus and Froend, 2006; US Forest Service, 2012). Phreatology is a field of interdisciplinary research focusing on the geological, hydrological, biological and chemical processes at the interface of the phreatic water with the vadose or surface waters (Batelaan, 2006). This field is restricted to unconfined, phreatic GW. While leaky-confined or confined aquifers are sometimes ecohydrogeologically important when close to the surface, these cases are not included in phreatology. Reiss and Chifflard (2017) discuss an integrative approach for spring habitats within the Earth's Critical Zone (Brantley et al., 2007), seeking coupling of perspectives between ecohydrology and hydropedology. Steube et al. (2009) note that legislation has started to consider groundwater not only as a resource but also as an ecosystem, and discuss attempts for an integrative concept of the ecological assessment of groundwater systems. Limnogeology (Gierlowski-Kordesch, 2003) is a branch of paleolimnology devoted to the study of lake systems and their deposits. Paleolimnology sometimes requires combining hydrogeological and ecological parameters. Zheng et al. (2019), for instance, reconstructed peatland hydrology (mire water-table depth) using testate-amoeba assemblages. Research on groundwater-surface-water (GW-SW) interactions examines the interface between aquifers and rivers, and emphasizes relationships among spatial and temporal variation in hydrological, physical, biogeochemical, and ecological factors (Larned et al., 2015). Stevens et al. (2019a) review GW-SW interactions influencing the hydrologic cycle at the watershed scale, noting that springs and (often GW-fed) lakes provide base flow for virtually all the rivers in non-ice-dominated portions of Earth. They also conclude that the role of GW in fluvial ecology has been considerably underestimated and underappreciated. Geobotanical survey techniques have been used since the late 1950s for mineral prospecting and complement field-based studies in several disciplines (Brooks, 1988; Ustin et al., 1999). Such investigations also involve land management and monitoring, and their importance is becoming progressively more evident.

In contrast to the above concepts, the term "ecohydrogeology" has only occasionally been used in the literature (e.g., Kimberley and Coxon, 2015; Wang et al., 2015), without discussion of its utility and novelty and without attempting a clear, unambiguous definition. We propose the following definition for this term: "Ecohydrogeology is a unifying, synthetic field of study integrating the approaches from the ecological and hydrogeological sciences in the study of groundwaterrelated ecosystems, habitats, and organisms to advance science, stewardship, and policy". Etymologically, ecohydrogeology is built on a foundation of geology, which largely controls aquifer hydrology, and which in combination permit development of GW and GW-SW aquatic and riparian ecosystems. GDEs include fully subterranean microbial and invertebrate aquifer ecosystems, as well as aquifer-surface water linked ecosystems, such as submarine and surface springs and GW-fed streams, lakes, and oceans. Expanding the concept of GDE ecology by adding the physical-process underpinnings of geology and hydrology, ecohydrogeology emphasizes the linkage between the intrinsic geological heterogeneity of the subsurface with GW occurrence, emergence, geomorphology, and biology. This multidisciplinary interaction has 


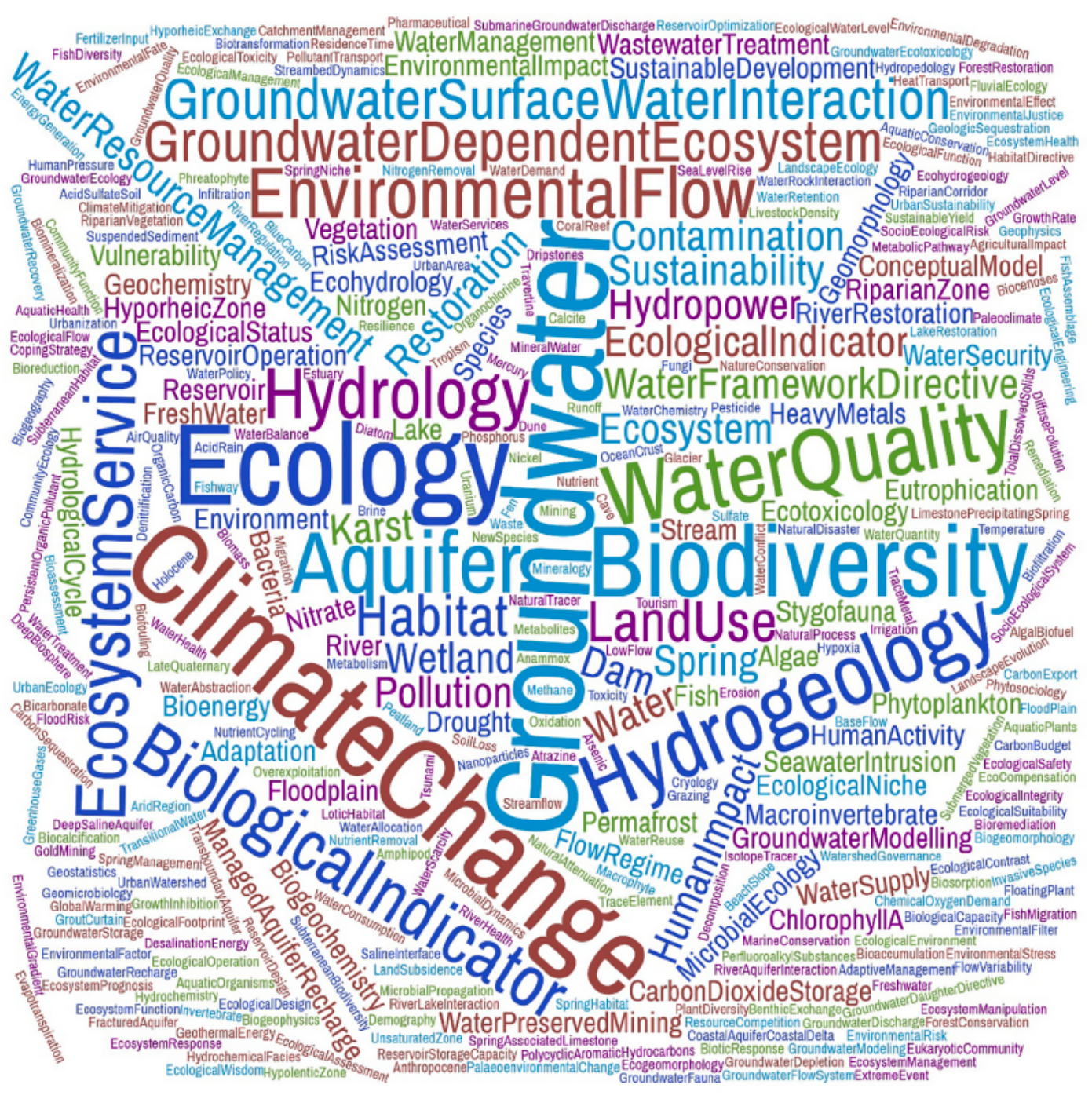

Fig. 1. Key word cloud constructed from SCOPUS search on the terms "ecology AND hydrogeology".

received insufficient attention, resulting in an oversimplified understanding of these important subsurface-surface ecological linkages. Increased scientific attention to ecohydrogeology will more clearly illuminate the advantages and challenges arising from in-depth integration of these three fields of science. The multidisciplinary integration we propose here among these three sciences will lead to the exploration of new conceptual realms, as well as identification of ecohydrogeological processes and indicators. In the following section we focus attention on ecological topics, case studies, and examples drawn from a SCOPUS bibliographic engine search of this topic from the literature, as well as our own studies.

\section{The elements of ecohydrogeology}

To portray the potential of ecohydrogeology as a field of research, we searched for all published records in the last $10.5 \mathrm{yr}$ ( 1 January 2009 through 14 August 2019) in the SCOPUS database using the search terms "ecology AND hydrogeology" (Fig. 1). Keywords were extracted from the resulting 495 records. The keyword list was refined by removing proper names (e.g., of places or organisms), non-specific words (e.g., data validation, scientific research, high density, etc.) or methodological terms (e.g., irregular time series, parameter uncertainty, box corer samples, etc.). This provided a list of 822 keywords, which subsequently were organized into a word cloud in which the size of a word is proportional to the number of times it occurred in the keyword list. Although not an exhaustive analysis, these data provide an informative visual image of the state of existing ecohydrogeological literature and the many themes associated with this multidisciplinary integration.

The key topics assembled in Fig. 1 overlap with many of the European Union environmental topics of priority such as "Nature and Biodiversity", "Climate Change", "L and and Soil", "Water", "Marine and Coastal Environment" (https://europa.eu/european-union/topics/ environment_en), and those of the Australian Water Act (2007, reviewed in Australian Productivity Commission. 2017, including "wholeof-cycle water management"). These policies highlight the international need and urgency for sustainable management of water resources, and will benefit from integration among ecological and hydrogeological approaches and water use policies. Similarly, many of the terms refer to environmental concerns in the USA, emphasizing Clean Water Act, Army Corps of Engineers, and Environmental Protection Agency regulation of water quality, as well as GDE ecology (e.g., Biksey and Gross, 2001; Alexander, 2015). In addition, Environment Canada (1987) identified the need for innovative science leadership and integrated planning across administrative and functional boundaries to balance water uses with societal and ecosystem needs.

It is notable that in our SCOPUS analysis, the term "ecohydrogeology" did emerge only twice, although it occasionally has received mention in the literature (e.g., Krause et al., 2007; Tomlinson and Boulton, 2010; Kimberley and Coxon, 2015; Wang et al., 2015; 
Sharaky, 2019). This indicates that this multidisciplinary integration not yet gained the attention of the scientific community. Also, the terms geology, evolution, and conservation were inconspicuous in the word cloud, indicating that the temporal scaling that so strongly influences those fields has not been integrated into freshwater ecology. We discuss these and other issues throughout the rest of this paper.

\section{Springs and crenoecology}

\subsection{Spring sources as a central focus for the converging fields of ecology} and hydrogeology

Springs are ecotones in which aquifer-surface components are linked across aquatic, wetland, and riparian systems where GW emerges. These usually flow from the Earth's surface and include subaqueous (e.g., submarine) as well as subaerial settings (Springer et al., 2008). Among the world's most socio-ecologically interactive, intriguing, diverse, and threatened ecosystems, spring ecohydrogeology has been insufficiently-studied by th e sc ientific, and ins ufficiently re-cognized as worthy of protection by the public and the management/governance communities. The study of springs has been hindered by the highly incomplete knowledge of their distribution, density, and types across landscapes. An accumulation curve analysis of Death Valley National Park, one of the landscapes with the best know distribution and densities of springs in N. America determined that there were likely many more undiscovered springs on the landscape (Junghans et al., 2016). Illies and Botosaneanu (1963) formally defined 'crenobiology' as the study of the biological properties of springs, and the term 'crenoe-cology' has been used sporadically in the literature over the last two decades (e.g., Cantonati et al., 2012). Springs are widely recognized as important habitats (Cantonati et al., 2012, 2015), creating complex ecotones and biodiversity hotspots (Cantonati and Lange-Bertalot, 2010; Cantonati et al., 2016; Taxböck et al., 2017), and thus also are ideal sites for long-term ecological research (Cantonati and Ortler, 1998).

Hydrogeologists and ecosystem ecologists converge at springs sources, but work in opposite directions. Hydrogeologists often conclude their studies at the point of emergence, while ecologists often initiate their research at that point. Thus, for hydrogeologists the source is the final point of $\mathrm{i}$ nterest i $\mathrm{n} t$ he a quifer, $w$ hile $\mathrm{f}$ or $\mathrm{e}$ cologists the source is the starting point of their study of GDE flow, habitats, and species in fens, ciénegas, or mires, hanging gardens, lakes, and asso-ciated lacustrine, palustrine, or fluvial riparian wetland zones (Fig. 2).

In many settings, GW discharge and surface water runoff intermingle, e.g.: hard-rock-aquifer mountain-stream reaches that directly receive GW discharge, and are fed only by GW during periods of hydrological recession without quick flow (overland flow + interflow), actually show a combination of GW-discharge and surface-water body features (e.g., Miller et al., 2016).

\subsection{Springs and other GDE classification}

As mentioned above, springs represent a water-dominated critical (=because it is essential to sustain life) zone at the interface between lithosphere, hydrosphere, and biosphere, but none of these fields of science by itself can fully embrace the phenomenology of physical, biological, and cultural interactions over time that constitute a spring ecosystem. On the geological side of springs research, hydrogeology is multidisciplinary among earth sciences and hydrological sciences, whereas ecosystem ecology also is strongly multidisciplinary but emphasizes a much different $l$ exicon, $s$ uite of $c$ oncepts, $v$ ariables, and study approaches. Bryan (1919), Meinzer (1923), Alfaro and Wallace (1994), Springer et al. (2008), and Glazier (2009) review the many spring classification topics and approaches that have been proposed.

Springs ecology is focused on the point of discharge of the GW, which is not considered SW or GW by some rules, regulations, or
Groundwater-flow system

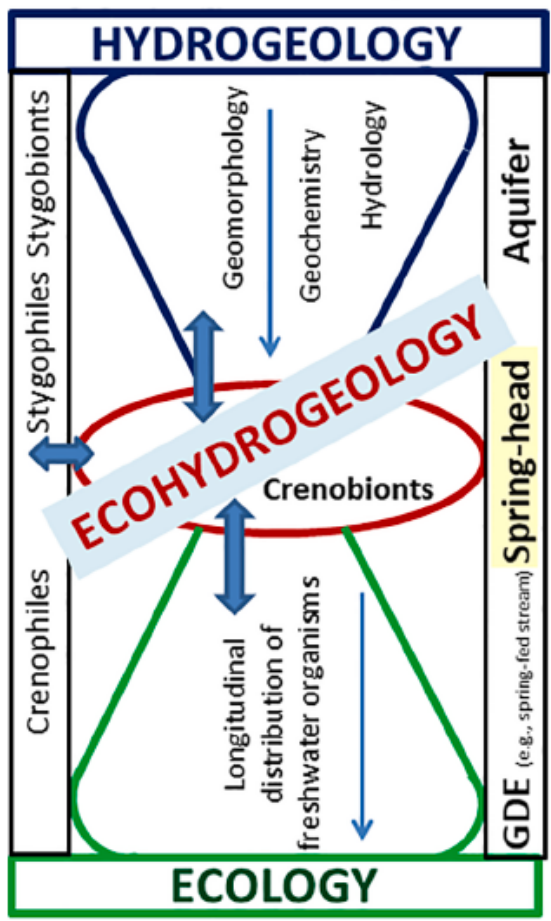

Surface-waters system

Fig. 2. Hourglass model of springs GW-SW ecotonal transitions (double arrows) as an emblematic example of synergistic ecological and hydrogeological approaches. Spring ecosystems are thus the iconic environment of ecohydrogeology (revised and redrawn from Cantonati et al., 2012).

policies. However, a growing body of literature identifies a suite of species not only dependent on springs, but restricted to discrete spheres of discharge and springs microhabitats (Springer and Stevens, 2009; Sinclair, 2018).

Nonetheless, springs are complex composite hydrogeological and ecological ecosystems and deserve a dedicated classification in order to provide a systematic framework necessary to study them. A variety of classifications have been presented in the literature from the hydrogeological stand-point, as well as from the ecological, crenobiological, and ecosystem-services perspectives. These two groups of classifications are useful and are utilized in an intra-disciplinary fashion by hydrogeologists or ecologists. However, they are rarely considered or taught to students outside of the individual disciplines. Table 1 provides a synthetic review of the main classification approaches that have been proposed, along with examples of references, some of which present additional literature compilations.

From the hydrogeological standpoint, basic classifications rely primarily upon: parent rock geology (lithology, stratigraphy) and structural geology of the groundwater basin; driving force mechanism (gravity, pressure or density/temperature dominated discharge), GW quality including water temperature and/or geochemistry; discharge quantity (magnitude, variability, and recession); or the geomorphology of the discharge point of the spring (the "sphere of discharge" as landform pattern at the springs source; Meinzer, 1923). Stevens et al. (2019b) emphasize that of the proposed classification factors, only geomorphology clearly and unambiguously distinguishes springs types.

From ecological and anthropogenic perspectives, the focus of springs classification may be physical and/or biological, depending on taxonomic composition, in addition to the structural or functional properties of the associated biota and assemblages. Early attempts to identify features determining spring characteristics particularly relevant for the colonizing biota are attributable to van der Kamp (1995), 


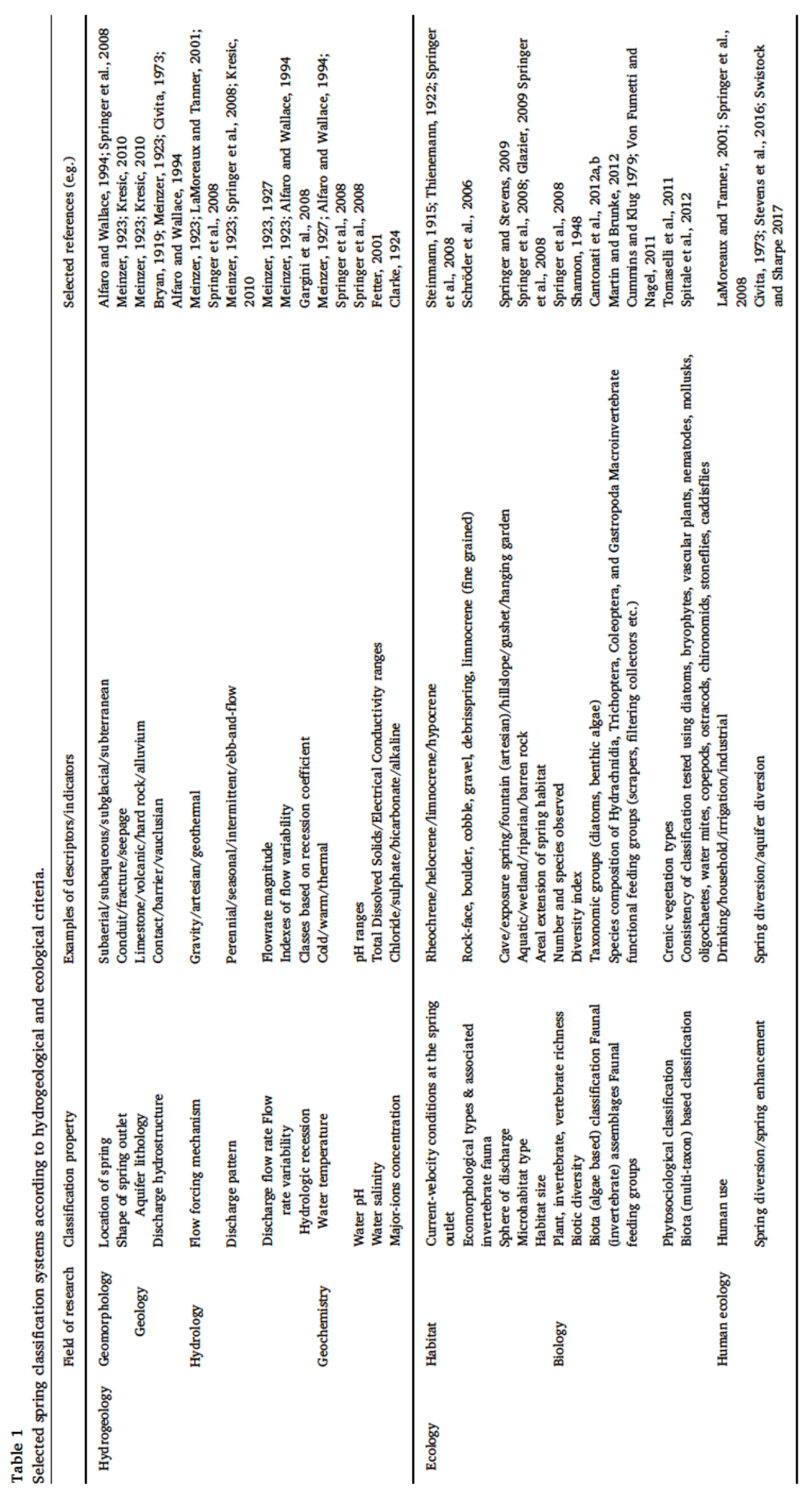


who demonstrated that the hydrological stability of many springs and springs-associated biota is determined by the hydrogeological features of the parent aquifer. The proposed classifications are generally related to natural GDE conditions, not to springs that have been diverted for human use or created by anthropogenic activities. However, the majority of springs in many landscapes have been dominated by human activities for millennia (e.g., Haynes, 2008 in North America; Cuthbert and Ashley, 2014 in the Old World), and are today partially or fully diverted, ecologically impaired, or obliterated (Stevens and Meretsky, 2008; e.g., Ledbetter et al., 2019). Because humans have relied on and altered springs throughout our evolution and history, our impacts must be taken into account in both research and stewardship (Stevens et al., 2016).

\subsection{Freshwater springs lithology/geology and biota}

The physical and chemical characteristics of emerging groundwater are determined by the geological settings and regional climate features, and often are modified by the indirect and direct impacts of human activity elsewhere (in Fig. 2 all environmental influences and impacts on the aquifer-spring-surface-water system can be influenced by anthropogenic activities). Such water quality interactions directly influence algal, macrophyte, invertebrate, vertebrate biodiversity, assemblage structure, and trophic dynamics.

\subsubsection{Algae}

Spring algal assemblages often largely constitute the aquatic foodbase of spring sources. These assemblages include both generalists and species that preferentially occur at spring sources and in comparable habitats (e.g., Cantonati et al., 2010, 2012c). Springs are often subjected to severe anthropogenic impacts, particularly alteration of the morphology of the springhead and contamination from increased nitrate concentrations. These impacts are clearly identifiable using diatom assemblages (e.g., Angeli et al., 2010). Werum and LangeBertalot (2004) studied the geologically-heterogeneous region around the city of Frankfurt (central Germany, Hessen). On the basis of hydrogeological criteria and hydrochemical analyses, eight spring groups could be recognized, and each of these was found to host its characteristic diatom assemblage. For epilithic (those living on stony and rocky substratum) algae and lichens, the lithology determining the hydrochemistry of the aquifer is generally more important than the petrography of the rocky material on which they grow. This was evident for calciphile species, such as the red alga Hildenbrandia rivularis and the aquatic lichen Verrucaria eleomelaena, thriving on igneous (granites, granodiorites, tonalities etc.) boulders and cobbles (covers by glacial quaternary deposits) at the site of emergence of springs with typical calcium-bicarbonate chemistry (limestone-dolomite aquifers) (M. Cantonati, unpublished data). Contrary to what is known for several groups of invertebrates, in particular water mites (e.g., Cantonati et al., 2012), few diatom species occur exclusively in springs (crenobiontic taxa; one exception may be Gomphonema montezumense Czarnecki and Blinn, 1979). However, there are diatom species that occur preferentially in springheads + spring-fed streams, and comparable habitats. For example, Cymbella tridentina is characteristic of springs and the upper part of spring-fed streams in the Dolomites and calcareous Alps (Cantonati et al., 2010). Algae and cyanobacteria turnover can occur when the geological substratum changes, and so called 'vicariant species' replace each other. For instance, the cyanoprokaryote genera Chamaesiphon and Tapinothrix are particularly common in mountain, relatively pristine waters but Chamaesiphon fuscus occurs in the low-conductivity waters of igneous rocks and is replaced by $C$. geitleri in the more mineralized waters on limestones and dolostones. Analogously, Tapinothrix janthina occurs in low alkalinity waters on hard rocks, to be replaced by T. varians on carbonate rocks (e.g., Cantonati et al., 2015). The diatom Achnanthidium dolomiticum (Cantonati and Lange-Bertalot, 2006) was described from the Dolomites
(Dolomiti Bellunesi, eastern Alps, Italy) a s t ypical f or a quatic habitats characterized by dolostone i nfluence on their GW-flow system. The species c ould a lso be $\mathrm{c}$ haracterized a s e piphytic ( living on plant-like substratum, f or i nstance on bryophytes i n springs, or on vascular plants i n lakes), and typically i nhabiting the depth $z$ one influenced by water-level $\mathrm{f}$ luctuations $\mathrm{i} \mathrm{n}$ lakes and springs a ffected by discharge f luctuations ( Cantonati et a l., 2012). More recently, $A$. dolomiticum was found also i $\mathrm{n}$ springs emerging f rom ophiolitic rocks, mainly peridotite a nd serpen-tinite ( Kamberović et a l., 2019), and $t$ his $c$ onfirmed a supposed pre-ference of $t$ he species $f$ or a boveaverage magnesium c oncentrations.

\subsubsection{Vascular plants}

Some aquatic and terrestrial vascular plant species are nearly or entirely restricted to springs. For example, aquatic Texas wild rice (Zizania texana) occurs only along the spring-fed headwaters of the San Marcos River in Texas (Poole and Bowles, 1999). Spring-supported alkaline meadows in Ash Meadows, Nevada support several endemic plant species (i.e., Nitrophila mohavensis and Zeltnera namophilum; Beatley, 1977). Floating-mat and iron-precipitating fens in central Rocky Mountains support populations of the rare roundleaf sundew plants (Drosera rotundifolia; Wolf et al., 2006).

\subsubsection{Invertebrates}

The global list of crenobiontic invertebrates is enormous, but no comprehensive global list has, to our knowledge, yet been developed. Synopses of regional springs-dependent invertebrates include those of Williams and Danks (1991), Erman and Erman (1990), Botosaneanu (1998), Spitale et al. (2012), and Springs Online (Springs Stewardship Institute, 2019), as well as other reviews. Among the most comprehensive analyses of crenobiont endemism and evolution is the work by Robert Hershler and his colleagues on North American Hydrobiidae springsnails (summarized in Hershler and Liu, 2017). Why the diversity of crenobiontic invertebrates so vastly outnumbers that of crenobiontic vascular plants remains unexplained.

\subsubsection{Vertebrates}

Rather many fish and amphibian species are springs-dependent, while numbers of reptilomorphs and higher vertebrates are relatively few. Springs dependence is abundantly evident among fish in arid regions, such as the American Southwest and central Australia (e.g., Minckley and Deacon, 1991; Unmack, 2001; Stevens et al., 2019b), but has been less intensively studied in mesic and tropical regions. Also, the role of springs in imprinting and homing of riverine and anadromous fish may be important but has received insufficient attention. Amphibians, such as the Amargosa toad, ranid frogs, and cryptobranchid hellbender salamanders often are endemic to springs or spring-fed reaches of headwater streams, and several species of garter snakes (Thamnophis spp.) are springs-dependent in the American Southwest (Stevens et al., 2019b). Only one bird population to our knowledge can be clearly described as springs-dependent: the southwestern USA population of American Dippers (Cinclus mexicanus), which nest exclusively near or behind madicolous flows in spring-fed headwater streams. In other portions of its range it nests in such habitats along higher order streams and rivers. Only a few North American mammal species can be considered crenophilic or crenobiontic, including Florida manatees (Trichechus manatus latirostris), which winter in the warmer waters of inland springs, and water shrews (Sorex palustris), which routinely forage in high elevation, high latitude spring-fed headwater streams.

\subsection{Karst ecohydrogeology, limestone precipitating springs (LPS), and biocalcification}

The water demands of approximately one quarter of global human population are met using GW obtained from karst aquifers (Ford and Williams, 2007). The huge practical relevance of karst aquifers, of 
which decision makers and the public need to recognize, ignited, among other initiatives, the World Karst Aquifer Mapping (WOKAM) project (Chen et al., 2017). WOKAM produced a world map and data-base of karst aquifers, also including selected karst springs and caves, acknowledging that karst springs are the "entrance" to karst conduits and caves. We regard this as a prominent example of how enhanced collaboration among disciplines can improve understanding and man-agement of karst ecohydrogeology and water supplies.

Karst a quifers and a ssociated habitats also a re relevant to regional biodiversity a nd e cology ( e.g., Goldscheider, 2019). S pecies in $t$ he genus Niphargus (Amphipoda) a re crustaceans $t$ hat a re endemic t o i n-dividual karst springs/aquifers; e.g., Fišer, 2012). For example, t he a mphipod Niphargus poianoi was described $\mathrm{f}$ rom the e vaporitic karst springs of Poiano i n northern Italy (Karaman, 1988). Not only small i nvertebrates, but a lso large species $c$ an be endemic of karst a quifers (e.g., large $f$ ish i $n$ karst $i$ nland desert springs i n t he Arabian Peninsula; Krupp, 1992).

The structural-stratigraphic $f$ ramework of $t$ he subsurface influences $t$ he hydrologic system by compartmentalizing GW f low pathways and water quality, and consequently $t$ he surface expressions of mineral spring deposits, t he accumulation of which often a re mediated by bio-logical a ctivity ( see e.g. Pedley, 2009; Jones and Renaut, 2010 and references $t$ herein). In $t$ his framework, calcium c arbonate accumulation in LimestonePrecipitatingS prings ( L PS;see Cantonati et a 1., 2016) represents the vast majority of $c$ ases, with deposits $f$ rom $t$ hermal springs commonly t ermed as "travertines", and the ones originated f rom non-thermal springs c ommonly t ermed as "tufas" ( e.g., Golubić et al., 2008; Cantonati et a 1., 2016).

For such situations the necessary $\mathrm{CO}_{2}$ commonly is derived from the atmosphere and/or the soil cover (e.g., Celico et al., 2010). None-theless, deeper sources related for instance to hypogenic processes such as anaerobic degradation of hydrocarbons (e.g., Chakraborty and Coates, 2004) and metamorphism of carbonate rocks (e.g., Ague, 2000; Bissig et al., 2006), also represent important contributions to the de-velopment of such deposits, in which the role of the geological back-ground appears to be even more important. A showcase example of such deep surface-subsurface interaction is represented by HC-related cold seeps detected on modern sea floor (Laming et al., 2018).

The approach used in the hydrocarbon industry for the characterisation of dual porosity-permeability reservoir systems (e.g., Spence et al., 2014), can be used to describe GW permeation in terrestrial settings. Subsurface structural-stratigraphic heterogeneity, in fact, controls the distribution and efficiency of GW flow pat hways, given favourable biological, physical, and chemical boundary conditions for L PSformation at their emergence (see e.g. Pedley, 1990; Ford and Pedley, 1996; Pentecost, 2005; Pedley, 2009; Jones and Renaut, 2010, and references therein). Recently, a general, comprehensive model has been developed by Cantonati et al. (2016), by subdividing LPS on the basis of their integrated geological background. According to this classification, $\mathrm{f}$ racture-related $\mathrm{c}$ ontribution $\mathrm{t}$ o permeability-porosity appears crucial, with a continuum of processes-products from gravitational to tectonic end members. In this framework, vertically persistent (deep-reaching) tectonic faults and large-scale fracture corridor systems may promote rise of hypogenic $\mathrm{CO}_{2}$-charged $\mathrm{GW}$, related or unrelated to magmatic/hydrothermal activity (thermal and non-thermal), with $\mathrm{CO}_{2}$ likely provided by oxidation of thermogenic methane or meta-morphism of deeply buried carbonate rocks (e.g., Frery et al., 2015).

From a practical standpoint, hydrogeology helps predict LPS location (Cantonati et al., 2016). This is a crucial factor considering that LPS are the only widespread spring type included in the Annex I of the Habitat Directive (EU-HD, 1992). LPSs harbour unique biota, including calcifying mosses (e.g., Eucladium verticillatum and Palustriella commu-tata), cyanoprokaryotes and diatoms, and, in particular, the peculiar and habitat-specific d esmid $\mathrm{m}$ icroalga $O$ ocardium s tratum, a s w ell as vascular plants (Cochlearia bavarica, Brassicaceae), midges ("chir-onomid tufa" inhabited by Tanytarsus reissi), caddisflies (Rhyacophila pubescens), and even a calcium-carbonate encrusted moth fly (Pericoma trifasciata gr., Diptera Psychodidae) (Cantonati et al., 2016).

In light of these close relationships, LPS studies on both the modern (actual ecosystem) and ancient (paleo-spring ecosystem) counterparts, can provide insight into short-term and long-term behaviour of subsurface fluid flow. Specifically, high-resolution stratigraphy coupled with geochemical fingerprinting (major and trace elements) and stable isotope analyses (e.g., C, O, Sr) can provide crucial information when matched with other archives. By isolating "normal" baseline trends, the punctuated signal of extreme climatic and/or tectonic events (e.g., floods, earthquakes) inferred to influence GW geochemistry (e.g., mixing of different fluid sources) and flow regime (e.g., variations in transmissivity-interconnetivity of the matrix-fracture network) can be recognized and used to validate modeling of combined tectonic-climatic events in the recent geological record (Cantonati et al., 2016 and citations of examples therein).

The peculiar photoautotrophic component of LPS biota (calcifying cyanobacteria, algae-especially the desmid Oocardium stratum, and mosses) also offers a unique opportunity to study the complex process of biocalcification. Hydrogeology is necessary for a correct understanding of $O$. stratum occurrence in springs and spring-fed streams (mineralization level of the water), and the longitudinal development of its niche in the spring-fed streams (governed by carbon dioxide degassing) (Rott et al., 2012).

To test Pfiester's (1976) hypothesis that Oocardium stratum is often overlooked because it develops in a habitat type rarely visited by phycologists, Trobej et al. (2017) studied algal communities only in springs with spring-associated limestone (SAL) deposits. They found the species in $50 \%$ of the sites studied, supporting the hypothesis that this species is more common than supposed, but that it occurs exclusively in habitats with very specific hydrogeological characteristics, as described above for LPS (see e.g., Cantonati et al., 2016). This is a typical example of a biogeographic pattern that needs an ecohydrogeological perspective for correct interpretation.

\section{Groundwater and GDE ecology}

\subsection{Groundwater-dependent ecosystems: classification}

Acknowledging that the role of GW in surface ecosystems is still insufficiently understood, Kløve et al. (2011) stress the importance of developing conceptual models to explain GW-environment interactions, and identifying hydrogeology and biodiversity as key aspects of GDEs. Bertrand et al. (2011) point out that GDE classification should be primarily achieved by highlighting the ecological roles of GW, with a focus on aquifer-scale processes, emergence-scale processes, and associated biocoenoses. Eamus et al. (2016) list hydrogeological indicators and biotic assemblages among the main techniques for identifying the location of GDEs in the landscape. Stevens et al. (2019b) emphasize that the utility and disambiguation of GDE classification can be greatly improved by employing an ecohydrogeological approach.

\subsection{GDEs and primary anthropogenic impacts}

The dependence of GDE on aquifer status relates quantitative or qualitative impairment of the aquifer to the geochemical and ecological integrity of the associated GW, springs, and other GDEs. Kløve et al. (2011) note that GDEs also are highly threatened by a plethora of different land-use activities, as well as land use changes and climate change. Groundwater pumping often is regarded as having a direct local impact on the aquifer; however, regional impacts also may occur. If not properly designed the construction of tunnels for large-scale transportation, energy schemes (high speed railways, motorways) and subterranean hydroelectric canals can generate irreversible regional impacts on GW discharge and GDEs (Cantonati et al., 2016). 
A recent and well documented case study concerns the High Speed Train line between Bologna and Florence through the northern Apennines (Italy). Between 1996 and 2009 a series of tunnels were drilled through sedimentary hard-rock aquifers, mainly represented by fractured turbiditic sandstones (Gargini et al., 2014). The tunnels, designed to lower the hydrostatic head, induced a water table drawdown over a radius of influence of up to $6 \mathrm{~km}$, causing the permanent or seasonal desiccation of a number of springs and spring-dominated stream reaches. The impacts were spread throughout fault and fracture zones connecting the tunnels to the surficial discharge points (Gargini et al., 2008). Hydraulic connectivity was convincingly demonstrated through tracer tests (Vincenzi et al., 2009; 2014). Now, 10 years after completion of the railway line, tunnel drainage has reached a steady state condition, and currently acts as a large spring, showing a discharge regime consistent with the local spring outflow regime. It has been estimated that $53 \%$ of the total amount of stream base flow $(700 \mathrm{~L} / \mathrm{s})$ was subtracted from natural runoff and is now discharged at a lower base level at the tunnel main portals (Vincenzi et al., 2014).

Other documented references about the impacts of tunnels against groundwater flow systems are presented in: Massoli-Novelli and Petitta, 1997; Petitta and Tallini, 2002; Masset and Loew, 2010. The first two refer to the highway tunnel through the Gran Sasso karst massif in Central Italy, while the latter refer to the hydrological effects of various tunnels drilled through crystalline and metamorphic hard rock aquifers in the Aar and Gotthard massifs (Switzerland).

These case studies emphasize that groundwater issues must not only be considered at local scales in relation to safety of drilling procedures and consolidation measures at the drilling face of the tunnel, but also at a broader spatial scale to minimize potential negative impacts on GDEs (Bertrand et al., 2011). Broader consideration and planning will provide protection and mitigation measures, such as more effective sealing of tunnels, and identify options such as sealing losing reaches of streams or creating small reservoirs to guarantee environmental flows.

\subsection{Ecohydrogeological indicators and GW flow systems (indicators of hydrological discharge)}

Spring-discharge changes reflected by shifts in electrical conductivity can influence spring biota. The appearance of Niphargus species (amphipod crustaceans) was examined in two studies in the northern Apennines (Italy): the Mt. Zirone and Mt. Prinzera ophiolite hard-rock aquifers (HRAs; Fig. SS1 in supplementary material). These isolated, $\mathrm{km}$-sized ultramafite bedrock bodies are bordered and underlain by aquitard units, predominantly characterized by polygenic breccias having a fine-grained matrix (Fig. SS2 in supplementary material). Spring flow and geochemistry was monitored daily to weekly for 16 months (Segadelli et al., 2017a,b). Electrical Conductivity at $25^{\circ} \mathrm{C}$ (EC) was positively related to the flow of perennial basal springs, located along the contact between ophiolite HRA and underlying aquitard (Segadelli et al., 2017a,b): EC increased with increasing flow during the charging phase (Fig. 3). In addition, depigmented, stygobiontic living specimens of niphargid amphipods, identified as Niphargus sp. aff. puteanus (Fig. SS3 in supplementary material; Bottazzi et al., 2011) appeared during discharge peaks. Correspondence between main precipitation peaks, flow-rate increases, and occurrence of niphargids is clearly recognizable in Fig. 4. Similar observations were made at a spring on Mt. Prinzera (P10 in Segadelli et al., 2017), but only during the autumnal recharge phase (Fig. 5). Segadelli et al. (2017a,b) developed a conceptual hydrogeological model (briefly summarized in $\mathrm{SM}$ ), through which we hypothesize that links between increased $\mathrm{Ni}$ phargus sp. aff. puteanus occurrences and EC values are due to enhanced spring flow rates, mainly caused by the arrival in the feeding aquifer of newly infiltrated waters with the consequent sudden increase in the hydraulic head. This abrupt increment and the subsequent pressure wave likely favoured mobilization of large volumes of deeper and more mineralized waters, along with the displacement of the hypogean organisms that live in the immediate vicinity of the spring (Fig. 6).

Among the possible practical implications, this approach can provide important benefits such as: - optimization of detection, monitoring and sampling activities of hypogean fauna; - use of the measured Niphargus dimensions (ranging from a minimum of a few millimeters to a maximum of $8 \mathrm{~mm}$ ) as a proxy for pore/fracture dimensions; - fast tracking of intense pulses of concentration of chemical and physical parameters that may have a significant effect on spring biota.

Based on the conceptual hydrogeological scheme outlined (Segadelli et al., 2017a,b), it is possible to assume that deep GW circulation over a hydrological year can influence the seasonal behaviour of the hypogean organisms living in the feeding aquifer, along with controlling the EC fluctuations in the associated spring waters and the possible concentrations of other chemical components present in spring waters. Such effects suggest a strong control of the subsurface structural-stratigraphic architecture on directional preferential pathways of GW flow and aquifer compartmentalization, in a way conceptually similar to the "plumbing" system developed for karst settings (see below).

\subsection{Flow in karstic systems: nutrients \& scenic red dinoflagellate blooms (Lake Tovel)}

Lake Tovel in the Brenta Dolomites (Italy, southeastern Alps, Unesco World Heritage site) was known as being affected by red dinoflagellate blooms which ceased in 1964. This lake is characterized by a karstic drainage in the upper part of the drainage basin, and by a pseudokarstic circulation around the lake, due to the presence of a thick glacial deposit (Ferretti and Borsato, 2006). The porous nature of the upper part of the glacial rim is also the cause of marked seasonal water-level fluctuations (WLFs), and the lake has been used also as a model system for lakes affected by relevant natural WLFs (e.g., Cantonati et al., 2014a,b). Also planktic rotifer-crustacean interactions could be shown to be mainly driven by water-residence-time (Obertegger et al., 2009). This ecohydrogeological approach ante litteram has provided definitive confirmation that the red discolouring was due to localized inputs of nutrient-enriched GW. The spatial distribution of the bloom within the lake, and its correlation with the points of GW input into the lake (perilacustrine, mostly submerged springs), and identified using the tracers uranine and tinopal CBS-X, confirmed that the mass dinoflagellate proliferation was a localized reaction to nutrient input. This inflowing water was affected by sewage generated by cow cattle-barn management practices before 1965 (Borghi et al., 2006). The use of tracers also showed that the hydrology of the lake was dominated by GW input and flow through the lake (Ferretti and Borsato, 2006). This inspires us to reconsider this classical study site using an ecohydrogeological perspective, considering it primarily in relation to GDE interactions.

\section{Phreatophytes and phytoscreening}

\subsection{Ecophysiology of phreatophytes and water-table depth and fluctuations}

The clear relationship between phreatophytes and GW depth and discharge has long been known in arid and semi-arid regions (e.g., Nichols, 1994; Stevens et al., 2019a). For regions with more humid climate such relationships are less obvious and have been studied more recently. Several studies bear mention. Batelaan et al. (2003) used phreatophytic vegetation to calibrate numerical GW models and L oheide et al. (2005) investigated the methods of White (1932) to analyze well hydrographs to estimate GW consumption by phreatophytes. The roots of these species reach to and into the water table, and can cause daily oscillations of the water-table depth, data on which can be used to estimate water consumption. Study of a Kansas riparian system demonstrated that maximum depth of phreatophyte roots depends on maximum water-table depth, confirming the value of a $\mathrm{GW}$ hydrology perspective (Butler et al., 2007; Nippert et al., 2010). At 


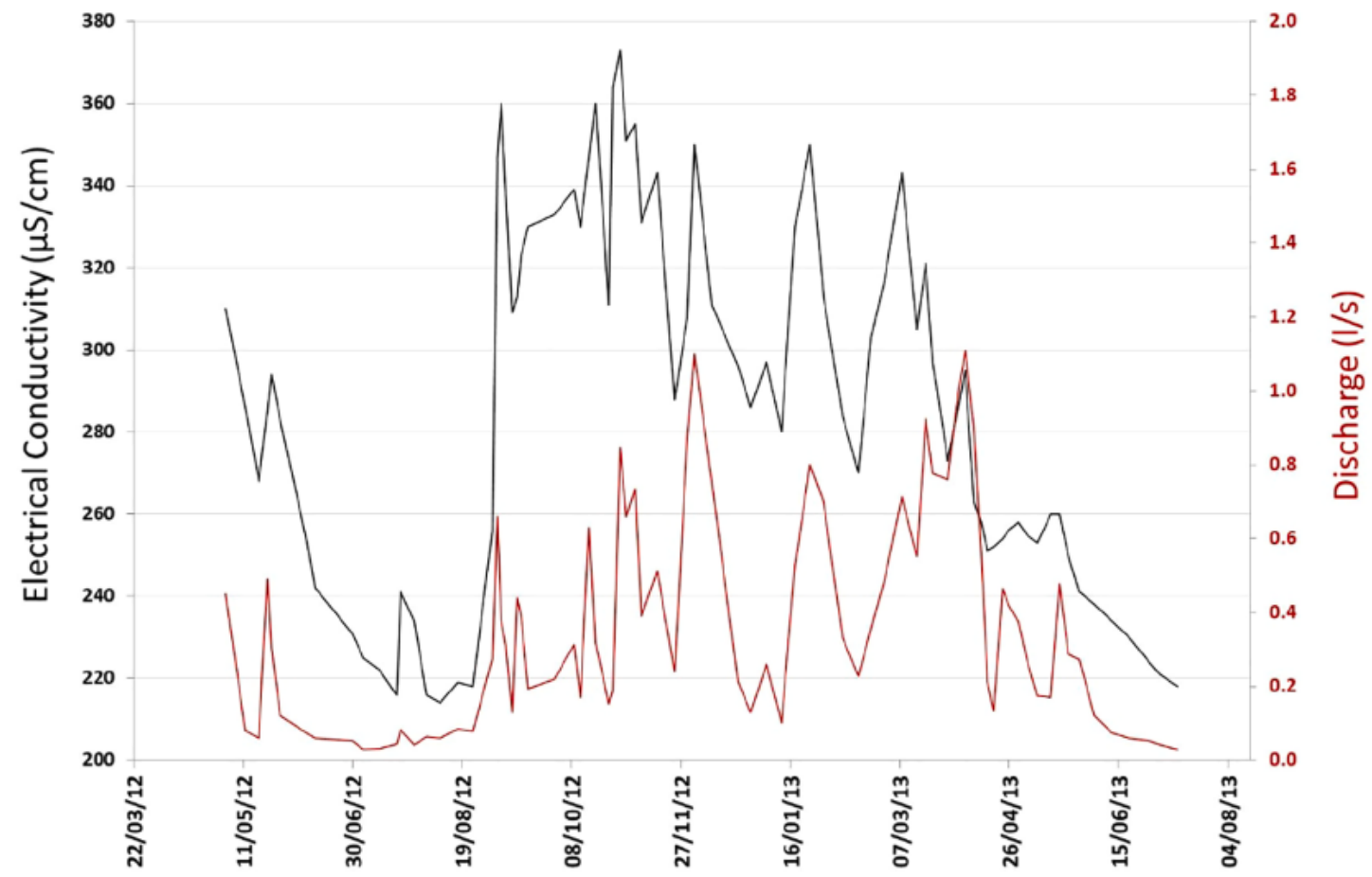

Fig. 3. Example of flow hydrograph (red line) of a basal perennial spring monitored in the Mt. Prinzera area (P03 in Segadelli et al., 2017a,b) showing discharge rates vs. time variations of the electrical conductivity (black line).

some sites, subsurface strata with water-retaining capability ensured the permanence of water in the vadose zone during water table subsidence, while shallow aquifers dominated by sand and gravel could be entirely drained by phreatophyte water uptake. The hydrogeology of those sites thus is crucial for understanding of phreatophyte distribution and development. Surprisingly not only plant-physiologists but also ecohydrologists have not given much attention to daily water-table oscillations, which are an excellent proxy of phreatophyte activity (Butler et al., 2007). Also, invasive plant species, such as the salt cedar (Tamarix ramosissima $\times$ chinensis hybrids), in the American Southwest can rapidly shift water sources in response to water-table declines, and thus minimize water stress during drought periods. Unfortunately,

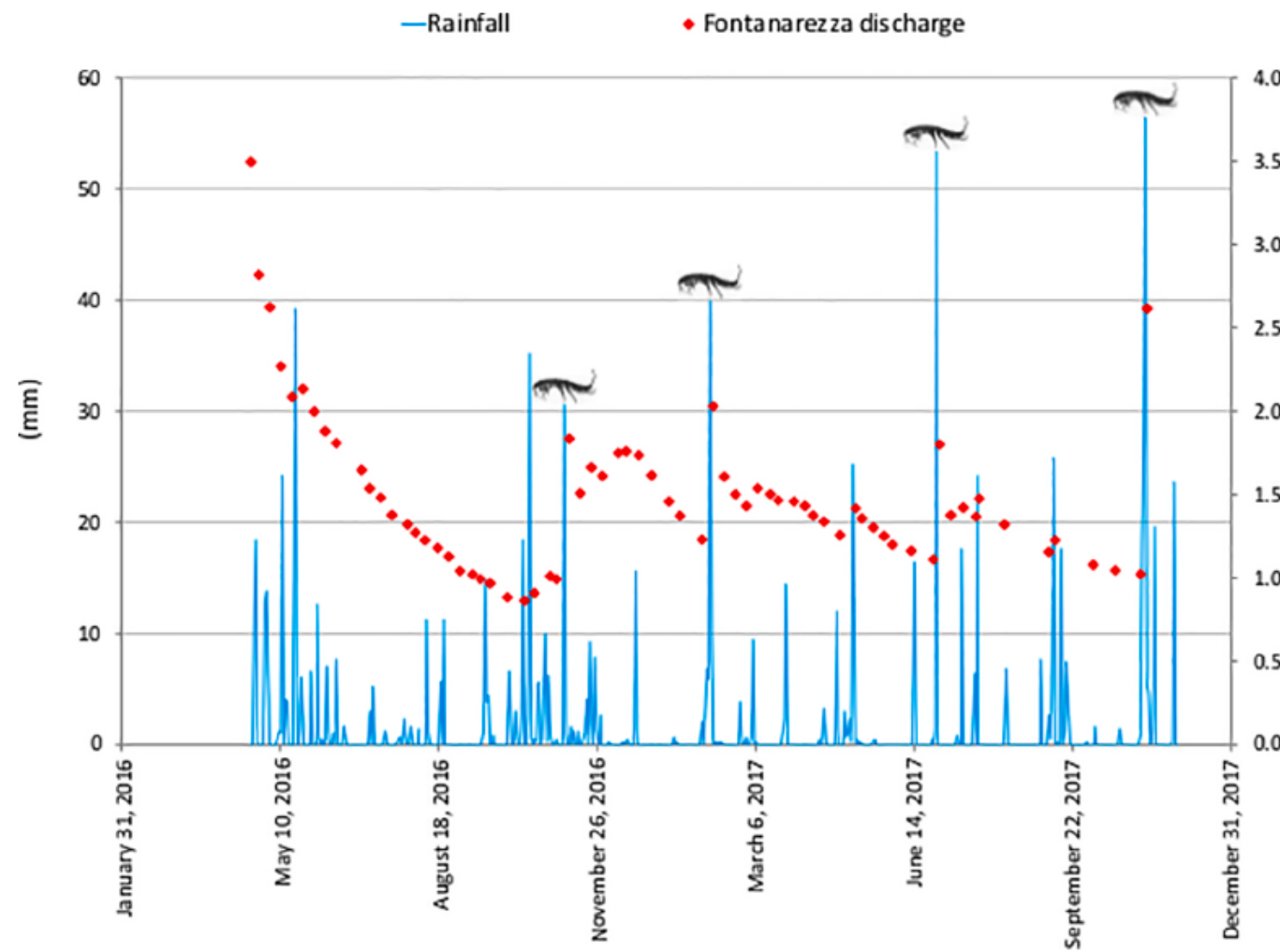

Fig. 4. Flow rate (red dotted line), Niphargus occurrences, and precipitation data (blue bar histogram) obtained from the basal spring (Z04), monitored in the Mt. Zirone area (Fig. SS4 in supplementary material). 


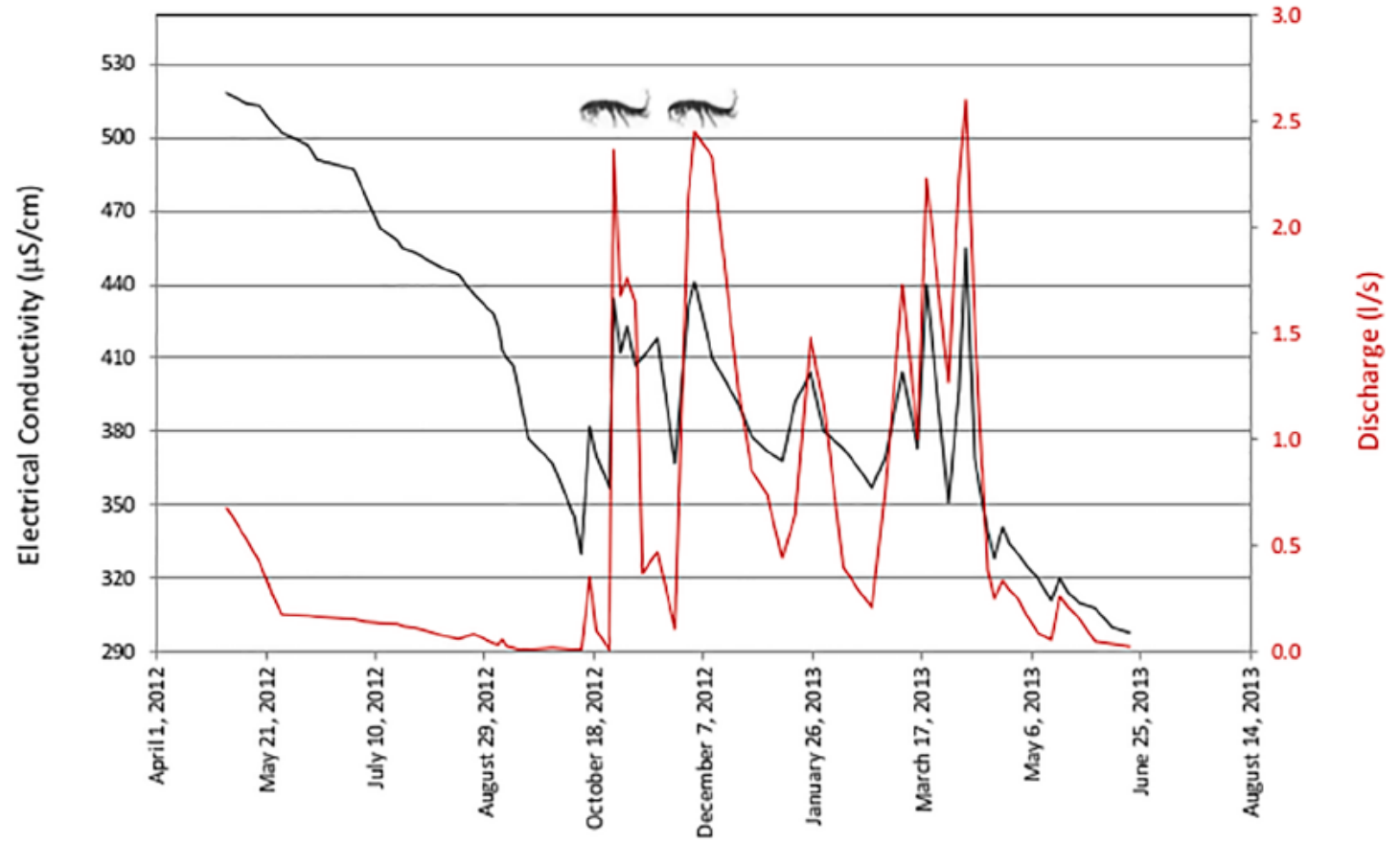

Fig. 5. Flow-discharge rate (red line) and electrical conductivity (black line) temporal variations in a basal perennial spring monitored in the Mt. Prinzera area (P10 in Segadelli et al., 2017a,b) and Niphargus occurrences.

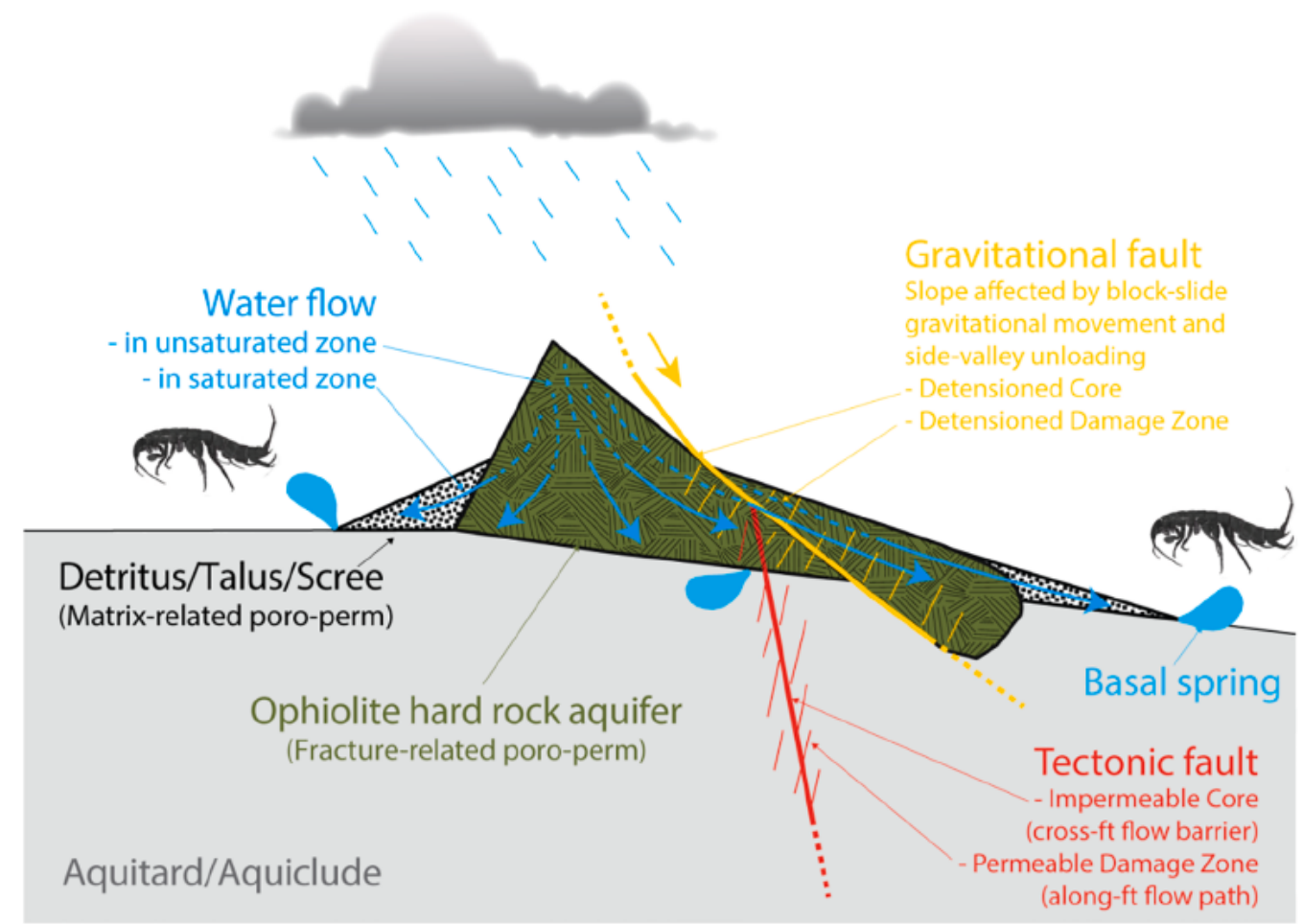

Fig. 6. Conceptual representation of the hydrostructure of a faulted and fractured hard-rock aquifer with location of the springs discussed for the Niphargus case study (Segadelli et al., 2017a,b).

many native southwestern Salicaceae and other riparian tree and shrub species have little capacity for such changes.

Stevens et al. (2019b) reported that f luvial southwestern riparian plant species were stratified by stage due $t o$ xylem water potential $\left(\Psi_{\mathrm{p}}\right)$ physiology and $\mathrm{t}$ he depth $\mathrm{t} o \mathrm{t}$ he riverine water table. Wetland species c onsistently had higher midnight and mid-day $\Psi_{\mathrm{p}}$, while riparian spe-cies except Tamarix spp. had somewhat lower $\Psi_{\mathrm{p}}$, upper riparian $\mathrm{z}$ one Prosopis and Senegalia had low $\Psi_{\mathrm{p}}$, and adjacent desert upland $\mathrm{t}$ axa had the lowest $\Psi_{\mathrm{p}}$ values. S uch $\mathrm{f}$ indings i ndicate t hat t he e cophysiology of phreatophyte a ssemblages $\mathrm{c}$ an serve as a ccurate $\mathrm{i}$ ndicators of shallow a quifer depth and $\mathrm{c}$ hange.

\subsection{Phytoscreening as an indicator $G W$ quality}

In the past few decades, trees have been used as biondicators of environmental pollution (Vroblesky, 2008). As trees transpire GW, 
many dissolved constituents are translocated, thus the plant works as a passive sampler of GW chemistry and contamination (Burken et al., 2011; Limmer et al., 2014). A variety of compounds from subsurface contamination can be taken up by plant roots, including heavy metals and volatile organic compounds (VOCs), such as BTEX and chlorinated hydrocarbons (e.g., Algreen et al., 2014; Algreen et al., 2015a; Vroblesky, 2008). Besides the well-known application of phytoremediation, the ability of trees to assimilate pollutants also is exploited for GW quality screening or monitoring (i.e. phytoscreening and phytomonitoring; Sorek et al., 2008). Underground contaminants transferred into trees are generally detected using minimally invasive techniques, such as trunk core samples or, less frequently, branch or leaf samples (e.g. Duncan et al., 2017; Gopalakrishnan et al., 2007).

Duncan and Brusseau (2018) reviewed a large number of previous studies on phytoscreening in sites contaminated by chlorinated ethenes (CEs) and reported a linear correlation between tree and shallow GW contaminant concentrations where the roots interact directly with contaminated GW. A much poorer correlation was found for deep GW contamination, even though CEs in trees were associated with GW contamination down to $19 \mathrm{~m}$ below the surface (e.g., Vroblesky et al., 2004; Sorek et al., 2008; Duncan et al., 2017). Recent work shows better correlation between tree and soil (Struckhoff et al., 2005), as well as between trees and soil CEs gas concentrations (Yung et al., 2017; Wilson et al., 2018), suggesting a new potential application of phyto-screening for vapour intrusion risk assessment (Burken et al., 2011; Algreen et al., 2015b; Wilson et al., 2018). The literature about phy-toscreening in sites contaminated by metals and BTEX is sparse com-pared to that for CEs. Algreen et al. (2014) suggested that a linear correlation between metal concentrations in soil and trees may exist above a certain concentration threshold. To the best of our knowledge, correlations between GW and tree concentrations of metals or BTEX have yet to be investigated. Further research is needed to improve prediction on the use of phytoscreening for quantitative assessment of GW contamination. However, the technique has been proven effective on a qualitative level.

Among major applications from the literature, phytoscreening was used to: (1) detect unknown GW contamination (e.g., Sorek et al., 2008); (2) integrate the information from traditional hydrogeological investigations in remote locations (e.g. Holm and Rotard, 2011; Wilcox and Johnson, 2016); (3) date contamination events (e.g. Yanosky et al., 2001); (4) perform long term GW monitoring in sites of monitored natural attenuation or phytoremediation (e.g. Gopalakrishnan et al., 2007; Larsen et al., 2008); (5) detect contaminant degradation based on the concentration ratio between parent and daughter compounds (e.g., Limmer et al., 2011; Vroblesky et al., 2004).

6. Mutual gains and challenges in combining ecological and hydrogeological approaches

The existing terminology in ecohydrogeology already is too complex and divisive (e.g., hydro-geo-ecology, Zanini et al., 2018; hydroecology, ecohydraulics, limnogeology, etc.).

Reviewing palaeolimnology, Juggins (2013) appropriately asked if reconstructed variables are also ecologically important. GW-SW interactions science has focused on the interfaces between rivers and aquifers.

However, we think that combining hydrogeology with ecology, and choosing the most straightforward term to define those interactions are worthwhile. If these disciplines can agree on the definition of ecohydrogeology we recommend here, this broad field of research should be offering a promising theoretical framework for dealing with GW-associated ecosystems, habitats, and organisms (Fig. 7).

To further exemplify what we consider an ecohydrogeological approach, we provide two recent examples from the literature. Grover (2019) studied the relationships between GW levels, SW levels, and the distribution and habitat use of cyprinid fishes in a large spring complex, and found that temporal variation of SW levels was almost completely (97\%) explained by GW levels, that populations of both species studied became more fragmented as GW and SW levels declined, and that longterm reductions of shallow GW levels exceeding $40 \mathrm{~cm}$ eliminated most spawning and juvenile habitats. Similarly, Fuchs et al. (2019) compared ponderosa pine (Pinus ponderosa) dendrochronology between paired trees growing at or away from northern Arizona springs. They reported faster growth and greater ring complacency among trees living at springs as compared to those occurring in nearby upland habitats, and suggested that such relationships could be used to more closely examine and model climate-GW relationships and springs perenniality in relation to this economically-relevant forest conifer.

Among the mutual gains to be obtained by combining ecological and hydrogeological approaches, we identify the following:

- Unique opportunities to identify and determine ultimate determinants of ecological and ecosystem patterns, processes, and constituent elements;

- Hydrogeology can provide GDE ecology with a more deeply grounded understanding and predictive modeling of habitat resilience;

- Biology can provide new indicators ("tracers", "bio-assays") for and from hydrogeology.

Among the main challenges to this physical and biological disciplineL

- Barriers due to disciplinary attitudes, habits, lexicons, and networking;

- The tendency to work in disciplinary isolation (e.g., SW versus GW sciences);

- Funding for multi-disciplinary research requires multi-disciplinary review panels;

- Difficulties in collaboration among non-multi-disciplinary fields;

- More complex education, skill sets, and working attitudes needed for more effective physical-biotic ecosystem integration and synthesis.L

\section{Conclusions: it is time for integrated ecohydrogeology}

We demonstrate here that ecohydrogeology represents an important new form of integrated research, that springs ecosystem and sociocultural functions are fundamental to societal well-being, and that springs ecosystem ecology is too complex to be understood from a single-discipline context. Thus, we propose here a strongly integrated, interdisciplinary approach, one based on synergistic hydrogeological and ecological principles, one that is needed to study the environmental interactions of GW-dependent organisms, assemblages, habitats, and socio-cultural systems. Deeper understanding of GDEs will only be possible with due consideration given to collaborative interactions among the fields of hydrogeology and ecology.

It is our opinion that the integrated approach represented by the term ecohydrogeology has so far been only been used timidly in GDE research, in particular without a clear, formal definition. This concept holds great promise for many useful future applications, as we have demonstrated with emblematic case studies and emphasized the following explicit definitions:

Ecohydrogeology: The unifying, synthetic scientific field integrating the approaches of ecology and hydrogeology in the study of groundwater-related ecosystems, habitats, organisms, and sociocultural processes to advance understanding, stewardship, and policy.

Ecohydrogeological indicator: 1) a hydrogeological parameter that may greatly enhance in-depth understanding and modelling of species distribution and autecology, as well as assemblage 


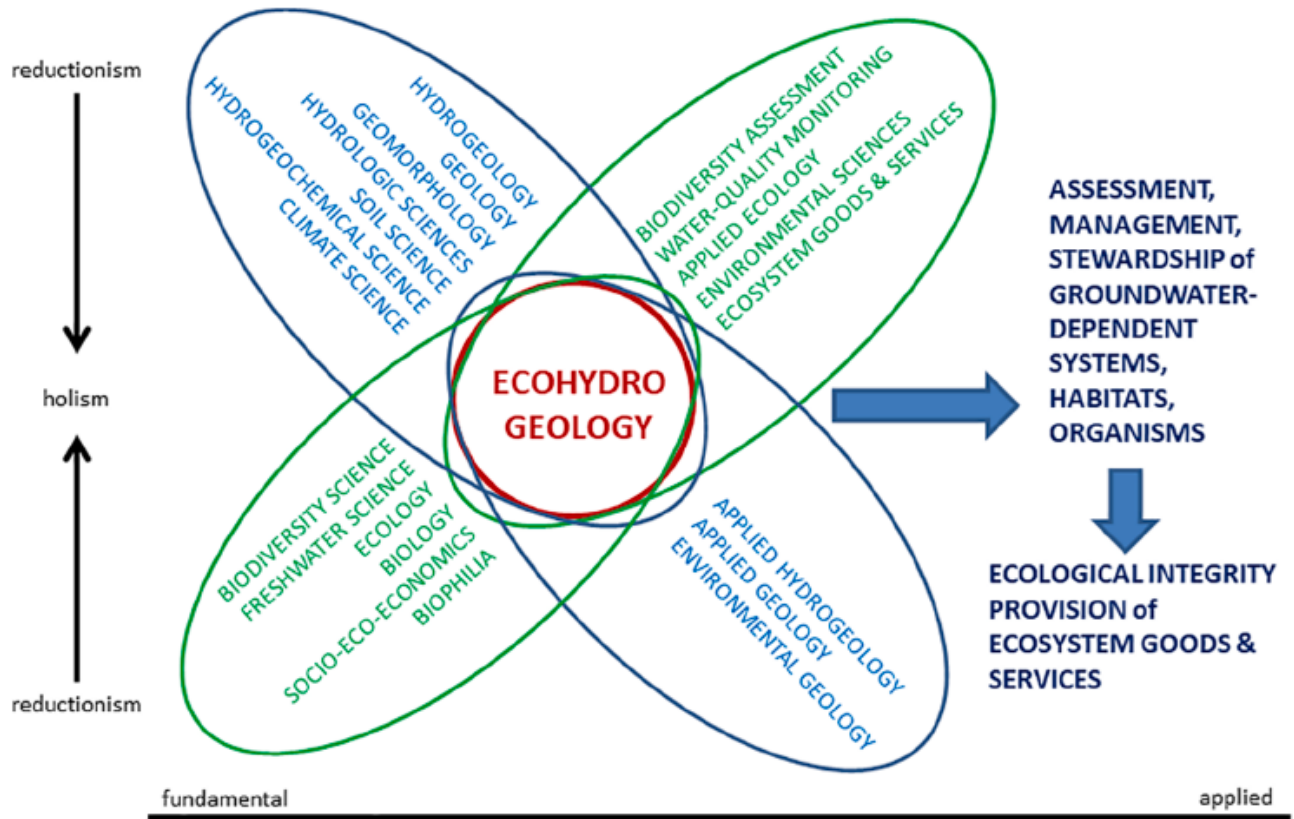

Fig. 7. The scientific domain of the unifying, integrative, multi-disciplinary field of ecohydrogeology and its applied consequences.

composition and drivers; and 2) a taxonomic or biocoenotic parameter that may serve as a strong indicator, and even a tracer, to infer variables and parameters of hydrogeological interest.

The key topics we identified in ecohydrogeology overlap with many EU, Australian, and USA environmental high priority topics, policies, and socio-cultural issues, including at least two United Nations Sustainable Development Goals.

\section{Acknowledgments}

MC is grateful to MUSE PAT (Trento, Italy) for allowing him to write this paper as part of the MUSE research theme on spring habitats and GDEs. L.EStevens thanks the Museum of Northern Arizona Springs Stewardship Institute and S.W. Carothers for support in preparation of this manuscript.

\section{Appendix A. Supplementary data}

Supplementary data to this article can be found online at https:// doi.org/10.1016/j.ecolind.2019.105803.

\section{References}

Ague, J.J., 2000. Release of $\mathrm{CO}_{2}$ from carbonate rocks during regional metamorphism of lithologically heterogeneous crust. Geology $28,1123-1126$.

Alexander, L.C.,2015. Science at the boundaries: scientific support for the clean water rule. Freshwater Sci. 34, 1588-1594.

Alfaro, C., Wallace, M., 1994. Origin and classification of springs and historical review with current applications. Environ. Geol. 24 (2), 112-124.

Algreen, M., Trapp, S., Rein, A., 2014. Phytoscreening and phytoextraction of heavy metals at Danish polluted sites using willow and poplar trees. Environ. Sci. Pollut.

Res. 21 (15), 8992-9001.

Algreen, M., Kalisz, M., Stalder, M., Martac, E., Krupanek, J., Trapp, S., Bartke, S., 2015a. Using pre-screening methods for an effective and reliable site characterization at megasites. Environ. Sci. Pollut. Res. Int. 22 (19), 14673-14686. https://doi.org/10. 1007/s11356-015-4649-6.

Algreen, M., Trapp, S., Jensen, P.R., Broholm, M.M., 2015b. Tree coring as a complement to soil gas screening to locate PCE and TCE source zones and hot spots. Ground Water

Monit. Rem. 35 (4), 57-66.

Alley, W.M., Beutler, L.,Campana, M.E., Megdal, S.B., Tracy, J.C., 2016. Groundwater visibility: the missing link. Groundwater 54 (6), 758-761.

Angeli, N., Cantonati, M., Spitale, D., Lange-Bertalot, H., 2010. A comparison between diatom assemblages in two groups of carbonate low-altitude springs with different levels of anthropogenic disturbances. Fottea 10, 115-128. https://doi.org/10.5507/ fot.2010.006.

Australian Productivity Commission. 2017. National Water Reform. Productivity Commission Report no. 87, Canberra.

Baron, J.S., Poff, N.L., Angermeier, P.L.,Dahm, C.N., Gleick, P.H., Hairston Jr., N.G. Jackson, R.B., Johnston, C.A., Richter, B.D., Steinman, A.D., 2002. Meeting ecological and societal needs for freshwater. Ecological. ESA Report. Ecol. Appl. 12 (5), 12471260.

Batelaan, O., 2006. Phreatology: Characterizing Groundwater Recharge and Discharge Using Remote Sensing, GIS, Ecology, Hydrochemistry and Groundwater Modelling. Vrije Universiteit Brussel, Department of Hydrology and Hydraulic Engineering, pp. 309.

Batelaan, O., De Smedt, F., Triest, L., 2003. Regional groundwater discharge: phreatophyte mapping, groundwater modelling and impact analysis of land-use change. J. Hydrol. 275, 86-108. https://doi.org/10.1016/S0022-1694(03)00018-0.

Beatley, J.C., 1977. Ash meadows. Nevada's unique oasis in the Mohave Desert. Mentzelia $3,20-24$.

Bertrand, G., Goldscheider, N., Gobat, J.M., Hunkeler, D., 2011. Review: from multi-scale conceptualization of groundwater-dependent ecosystems to a classification system for management purposes. Hydrogeol. J. 20, 5-25. https://doi.org/10.1007/ s10040-011-0791-5.

Biksey, T.M., Gross, E.D., 2001. The hyporheic zone: linking groundwater and surface water - understanding the paradigm. Remed. J. 12, 55-62.

Bissig, P., Goldscheider, N., Mayoraz, J., Surbeck, H., Vuataz, F.-D., 2006. Carbogaseous spring waters, coldwater geysers and dry $\mathrm{CO}_{2}$ exhalations in the tectonic window of the LowerEngadine Valley, Switzerland. Ecl. Geol. Helv. 99, 143-155.

Borghi, B., Borsato, A., Cantonati, M., Corradini, F., Flaim, G., 2006. The SALTO research project (2001-2004): a study on Lake Tovel. Studi Trentini di Scienze Naturali. Acta Biologica 81, 476 [in Italian].

Botosaneanu, L.(Ed.), 1998. Studies in Crenobiology: The Biology of Springs and Springbrooks. Backhuys, Leiden.

Bottazzi, E., Bruno, M.C., Pieri, V., Di Sabatino, A., Silveri, L., Carolli, M., Rossetti, G., 2011. Spatial and seasonal distribution of invertebrates in Northern Apennine rheocrene springs. In: Cantonati, M., Gerecke, R., I. Jüttner, I., Cox, E.J. (Guest Editors), Springs: neglected key habitats for biodiversity conservation. J. Limnol. 70(Suppl. 1), 77-92. DOI: 10.3274/JL11-70-S1-06.

Brantley, S.L., Goldhaber, M.B., Ragnarsdottir, K.V., 2007. Crossing disciplines and scales to understand the critical zone. Elements 3, 307-314.

Brooks, R.R., 1988. Geobotanical prospecting. General Geology. Encyclopedia of Earth Science. Springer, Boston, MA.

Bryan, K., 1919. Classification of springs. J. Geol. 27 (7), 522-561.

Burken, J.G., Vroblesky, D.A., Balouet, J.C., 2011. Phytoforensics, dendrochemistry, and phytoscreening: new green tools for delineating contaminants from past and present. Environ. Sci. Technol. 45 (15), 6218-6226.

Butler Jr., J.J., Kluitenberg, G.J., Whittemore, D.O., Loheide, S.P.I.I., Jin, W., Billinger, M.A., Zhan, X., 2007. A field investigation of phreatophyte-induced fluctuations in the water table. Water Resour. Res. 43, W02404. https://doi.org/10.1029/ 2005WR004627.

Cantonati, M., Ortler, K., 1998. Using spring biota of pristine mountain areas for long term monitoring. In: Hydrology, Water Resources and Ecology in Headwaters. IAHS Publ., pp. 379-385 248 .

Cantonati, M., Lange-Bertalot, H., 2006. Achnanthidium dolomiticum sp. nov. (Bacillariophyta) from oligotrophic mountain springs and lakes fed by dolomite aquifers. J. Phycol. 42, 1184-1188. https://doi.org/10.1111/ j.1529-8817.2006. 
00281.x.

Cantonati, M., Lange-Bertalot, H., 2010. Diatom biodiversity of springs in the Berchtesgaden National Park (northern Alps, Germany), with the ecological and morphological characterization of two species new to science. Diatom Res. 25, 251-280. https://doi.org/10.1080/0269249X.2010.9705849.

Cantonati, M., Komárek, J., Montejano, G., 2015. Cyanobacteria in ambient springs. Biodivers. Conserv. 24, 865-888. https://doi.org/10.1007/s10531-015-0884-x.

Cantonati, M., Lange-Bertalot, H., Scalfi, A., Angeli, N., 2010. Cymbella tridentina sp. nov. (Bacillariophyta), a crenophilous diatom from carbonate springs of the Alps. J. North Am. Benthol. Soc. 29, 775-788. https://doi.org/10.1899/09-077.1.

Cantonati, M., Füreder, L., Gerecke, R., Jüttner, I., Cox, E.J., 2012a. Crenic habitats, hotspots for freshwater biodiversity conservation: toward an understanding of their ecology. Freshwater Sci. 31, 463-480. https://doi.org/10.1899/11-111.1.

Cantonati, M., Angeli, N., Bertuzzi, E., Spitale, D., Lange-Bertalot, H., 2012b. Diatoms in springs of the Alps: spring types, environmental determinants, and substratum. Freshwater Sci. 31 (2), 499-524.

Cantonati, M., Guella, G., Spitale, D., Angeli, N., Borsato, A., Lencioni, V., Filippi, M.L., 2014a. The contribution of lake benthic algae to the sediment record in a carbonate mountain lake influenced by marked natural water-level fluctuations. Freshwater Sci. 33, 499-512. https://doi.org/10.1086/676471.

Cantonati, M., Guella, G., Komárek, J., Spitale, D., 2014b. Depth-distribution of epilithic cyanobacteria and pigments in a mountain lake characterized by marked water-level fluctuations. Freshwater Sci. 33, 537-547. https://doi.org/10.1086/675930.

Cantonati, M., Rott, E., Spitale, D., Angeli, N., Komárek, J., 2012c. Are benthic algae related to spring types? Freshwater Sci. 31 (2), 481-498.

Cantonati, M., Segadelli, S., Ogata, K., Tran, H., Sanders, D., Gerecke, R., Rott, E., Filippini, M., Gargini, A., Celico, F., 2016. Petrying springs: a global review on ambient limestone-precipitating springs (LPS): hydrogeological setting, ecology and conservation. Sci. Total Environ. 568, 624-637. https://doi.org/10.1016/j.scitotenv. 2016.02.105.

Carpenter, S.R., Stanley, E.H., Vander Zanden, J., 2011. State of the world's freshwater ecosystems: physical, chemical, and biological changes. Annu. Rev. Environ. Resour.

36, 75-99.

Cartwright, J.M., Dwire, K.A., Freed, Z., Hammer, S.J., McLaughlin, B., Misztal, L.W., Schenk, E.R., Spence, J.R., Springer, A.E., Stevens, L.E., 2019. Oases of the future? evaluating springs as potential hydrologic refugia in drying climates. Front. Ecol. Environ.

Celico, F., Naclerio, G., Bucci, A., Nerone, V., Capuano, P., Carcione, M., Allocca, V., Celico, P., 2010. Influence of pyroclastic soil on e11585/720676pikarst formation: a test study in southern Italy. Terranova 22, 110-115.

Chakraborty, R., Coates, J.D., 2004. Anaerobic degradation ofmonoaromatic hydrocarbons. Appl. Microbiol. Biotechnol. 64 (4), 437-446.

Chen, Z., Auler, A.S., Bakalowicz, M., Drew, D., Griger, F., Hartmann, J., Jiang, G., Moosdorf, N., Richts, A., Stevanovic, Z., Veni, G., Goldscheider, N., 2017. The World Karst Aquifer Mapping project: concept, mapping procedure and map of Europe. Hydrogeol. J. 25 (3), 771-785. https://doi.org/10.1007/s10040-016-1519-3.

Civita, M., 1973. Schematizzazione idrogeologica delle sorgenti normali e delle relative opere di captazione (hydrogeological classification of normal springs and their water abstraction methods [in Italian]. Memorie e note dell'istituto di geologia applicata dell'Università di Napoli 12

Clarke, F.W., (Ed.) 1924. The data of geochemistry. Department of the interior, United States Geological Survey, bulletin 770, Washington, D.C., pp. 841. https://doi.org/ $10.3133 / \mathrm{b} 770$

Cummins, K.W., Klug, M.J., 1979. Feeding ecology of stream invertebrates. Annu. Rev. Entomol. 18, 183-206.

Cuthbert, M.O., Ashley, G.M., 2014. A spring forward for hominin evolution in East Africa. PLoS One. https://doi.org/10.1371/journal.pone.0107358.

Czarnecki, D.B., Blinn, D.W., 1979. Observation on southwestern diatoms, part 2: Caloneis latiuscula var. reimeri n. var., Cyclotella pseudostelligera f. parva n.f. and Gomphonema montezumense $\mathrm{n}$. sp., new taxa from Montezxuma Well National Monument. Trans. Am. Microsc. Soc. 98, 110-114.

Downing, J.A., 2014. Limnology and oceanography: two estranged twins reuniting by

global change. Inland Waters 4, 215-232. https://doi.org/10.5268/iw-4.2.753. Duncan, C.M., Brusseau, M.L., 2018. An assessment of correlations between chlorinated VOC concentrations in tree tissue and groundwater for phytoscreening applications.

Sci. Total Environ. 616-617, 875-880.

Duncan, C.M., Mainhagu, J., Virgone, K., Ramírez, D.M., Brusseau, M.L., 2017 Application of phytoscreening to three hazardous waste sites in Arizona. Sci. Total Environ. 609, 951-955.

Eamus, D., Froend, R.H., 2006. Groundwater dependent ecosystems: the where, what and why of GDEs. Aust. J. Bot. 54, 91-96.

Eamus, D., Fu, B., Springer, A.E., Stevens, L.E., 2016. Groundwater dependent ecosystems: Classification, identification techniques and threats. In: Jakeman, A.J. Barreteau, O., Hunt, R.J., Rinaudo, J.D., Ross, A. (Eds.), Integrated, Groundwater Management: Concepts, Approaches and Challenges. Springer Nature, SW, pp. 313-347. https://doi.org/10.1007/978-3-319-23576-9.

Environment Canada, 1987. Federal Water Policy. Environment Canada, Ottawa http:// www.ec.gc.ca/water/en/policy/federal/e_pol.htm.

Erman, N.A., Erman, D.C., 1990. Biogeography of Caddisfly (Trichoptera) Assemblages in Cold Springs of the Sierra Nevada. California Water Resources Center, pp. 29 ISSN 0575-4941

EU-HD (European Union Habitat Directive), 1992. Council Directive 92/43/EEC of 21 May 1992 on the conservation of natural habitats and of wild fauna and flora (EC Habitats Directive). Off. J. Eur. Commun. L 206, 7-50.

Ferretti, P., Borsato, A., 2006. Hydrogeological study of Lake Tovel and its valley [in Italian]. Studi Trent. Sci. Nat, Acta Biol. 81, 189-203.
Fetter Jr., C.W., 2001. Applied Hydrogeology. Prentice Hall, Upper Saddle River, NJ. Fišer, C., 2012. Nịphargus: a model system for evolution and ecology. In: Culver, D.C., White, W.B. (Eds.), Encyclopedia of Caves. Academic Press, pp. 555-564.

Ford, T.D., Pedley, H.M., 1996. A review of tufa and travertine deposits of the world. Earth Sci. Rev. 41 (3-4), 117-175.

Ford, D., Williams, P., 2007. Karst hydrogeology and geomorphology. Wiley, Chichester, UK

Frery, E., Gratier, J.-P., Ellouz-Zimmerman, N., Loiseletc., Braun, J., Dechamps, P., Blamart, D., Hamelin, B., Swennen, R., 2015. Evolution of fault permeability during episodic fluid circulation: evidence for the effects of fluid-rock interactions from travertine studies (Utah-USA). Tectonophysics 651-652, 121-137.

Fuchs, L., Stevens, L.E., Fulé, P.Z., 2019. Dendrochronological assessment of spring flow on ponderosa pine growth. For. Ecol. Manage. 435, 89-96.

Gargini, A., De Nardo, M.T., Piccinini, L., Segadelli, S., Vincenzi, V., 2014. Spring discharge and groundwater flow systems in sedimentary and ophiolitic hard rock aquifers: experiences from Northern Apennines (Italy). In: Sharp, J.M. (Ed.), Fractured Rock Hydrogeology", IAH Series n²0. CRC Press, Balkema, pp. 129-146.

Gargini, A., Vincenzi, V., Piccinini, L., Zuppi, G., Canuti, P., 2008. Groundwater flow systems in turbidites of the Northern Apennines (Italy): natural discharge and high

speed railway tunnel drainage. Hydrogeol. J. 16 (8), 1577-1599.

Gierlowski-Kordesch, E.H., 2003. Limnogeology. Geotimes. http://www.geotimes.org/ july03/high_limnogeo.html.

Glazier, D.S., 2009. Springs. In: Likens, G.E. (Ed.), Encyclopedia of Inland Waters. Academic Press, Oxford, pp. 734-755.

Goldscheider, N., 2019. A holistic approach to groundwater protection and ecosystem services in karst terrains. Carbonates Evaporites. https://dol.org/10.1007/ s13146-019-00492-5.

Golubić, S., Violante, C., Plenković-Moraj, A., Grgasović, T., 2008. Travertines and calcareous tufa deposits: an insight into diagenesis. Geol. Croat. 61, 363-378.

Gopalakrishnan, G., Negri, M.C., Minsker, B.S., Werth, C.J., 2007. Monitoring subsurface contamination using tree branches. Ground Water Monit. Rem. 27 (1), 65-74. Griebler, C., Avramov, M., 2015. Groundwater ecosystem services: a review. Freshwater Sci. 34, 355-367.

Grover, M.C., 2019. Effects of groundwater fluctuations on the distribution and population structure of two cyprinid fishes in a desert spring complex. J. Freshwater Ecol. 34 (1), 167-187.

Haynes Jr., C.V., 2008. Quaternary cauldron springs as paleoecological archives. In: Stevens, L.E., Meretsky, V.J. (Eds.), Aridland Springs of North America: Ecology and Conservation. University of Arizona Press, Tucson, pp. 76-97.

Hershler, R., Liu, H.-P., 2017. Annotated Checklist of Freshwater Truncatelloidean Gastropods of the Western United States, with an Illustrated Key to the Genera. Technical Note 449. U.S. Department of the Interior, Bureau of Land Management, National Operations Center, Denver.

Holm, O., Rotard, W., 2011. Effect of radial directional dependences and rainwater influence on CVOC concentrations in tree core and birch sap samples taken for phytoscreening using HS-SPME-GC/MS. Environ. Sci. Technol. 45, 9604-9610. https:// doi.org/10.1021/es202014h.

mlies, J., Botosaneanu, L., 1963. Problèmes et méthodes de la classification et de la zonation écologique des eaux courantes, considerées surtout du point de vue faunistique. Mitteil. Int Vereinig. Theoret. Angew. Limnol. 12, 1-57.

Jones, B., Renaut, R.W., 2010. Calcareous spring deposits in continental settings. In: Alonso-Zarza, A.M., Tanner, L.H. (Eds.), Carbonates in Continental Settings: Facies, Environments, and Processes 61. Elsevier, pp. 177-224.

Juggins, S., 2013. Quantitative reconstructions in palaeolimnology: new paradigm or sick science? Quat. Sci. Rev. 64, 20-32. https://doi.org/10.1016/j.quascirev.2012.12. 014 .

Junghans, K.M., Springer, A.E., Stevens, L.E., Ledbetter, J.D., 2016. Springs ecosystem distribution and density for improving stewardship. Freshwater Science 35 (4), 1330-1339. https://doi.org/10.1086/689182.

Kamberovic, J., Plenkovic-Moraj, A., Kralj Borojevic, K., Gligora Udovic, M., Žutinić, P., Hafner, D., Cantonati, M., 2019. Algal assemblages in springs of different lithology (ophiolithes vs. limestone) of the Konjuh Mountain (Bosnia and Herzegovina). Acta Botanica Croatica. https://doi.org/10.2478/botcro-2019-0004.

Karaman, G.S., 1988. Contribution to the knowledge of the Amphipoda. The new species of genus Nïphargus Schiödte (Gammaridea, fam Niphargidae) from Italy and Yugoslavia. Poljopriveda i Šumarstvo 34, 11-32.

Kimberley, S., Coxon, C., 2015. Developing status tests for selected Irish groundwaterdependent terrestrial ecosystem (GWDTE) types as part of groundwater body status assessment under the EU Water Framework Directive. Biol. Environ. Proc. R. Irish Acad. 115B (2), 1-14. https://doi.org/10.3318/BIOE.2015.07.

Kløve, B., Ala-aho, P., Bertrand, G., Boukalova, Z., Ertürk, A., Goldscheider, N., Ilmonen, J., Karakaya, N., Kupfersberger, H., Kværner, J., Lundberg, A., Mileusnic, M., Moszczynska, A., Muotka, T., Preda, E., Rossi, P., Siergieiev, D., Šimek, J., Wachniew, P., Angheluta, V., Widerlund, A., 2011. Groundwater dependent ecosystems. Part I: Hydroecological status and trends. Environ. Sci. Policy 14 (7), 770-781.

Krause, S., Heathwaite, A.L., Miller, F., Hulme, P., Crowe, A., 2007. Groundwater-dependent wetlands in the UK and Ireland: controls, functioning and assessing the likelihood of damage from human activities. Water Resour. Manage. 21 (12), 2015-2025.

Kreamer, D.K., Stevens, L.E., Ledbetter, J.D., 2015. Groundwater-dependent ecosystems science, challenges, and policy. In: Adelana, S.M. (Ed.), Groundwater. Nova Science Publishers, Inc., Hauppauge, pp. 205-230.

Kresic, N., 2010. Types and classifications of springs. In: Kresic, N., Stevanovic, Z. (Eds.), Groundwater Hydrology of Springs. Butterworth-Heinemann, Boston, pp. 31-85. Krupp, F., 1992. The karst springs of Ra's al-'Ain - a freshwater community in the Mesopotamian desert. Aqua Geogr. 1, 26-33. 
Laming, S.R., Gaudron, S.M., Duperron, S., 2018. Lifecycle ecology of deep-sea chemosymbiotic mussels: a review. Front. Mar. Sci. 5, 282. https://doi.org/10.3389/fmars. 2018.00282

LaMoreaux, P.E., Tanner, J.T., 2001. Springs and Bottled Waters of the World: Ancient History, Source, Occurrence, Quality and Use. Springer, Berlin Heidelberg. Larned, S.T., Gooseff, M.N., Packman, A.I., Rugel, K., Wondzell, S.M., 2015. Groundwater-surface-water interactions: current research directions. Freshwater Sci. 34 (1), 92-98. https://doi.org/10.1086/679491.

Larsen, M., Burken, J., Machackova, J., Karlson, U.G., Trapp, S., 2008. Using tree core samples to monitor natural attenuation and plume distribution after a PCE spill. Environ. Sci. Technol. 42 (5), 1711-1717.

Ledbetter, J.D., Stevens, L.E., Springer, A.E., Brandt, B., 2019. Springs Online Database: Springs and Springs-dependent Species. Vers. 1.0. Springs Stewardship Institute, Flagstaff < springsdata.org >

Limmer, M.A., Balouet, J.-C., Karg, F., Vroblesky, D.A., Burken, J.G., 2011. Phytoscreening for chlorinated solvents using rapid in vitro SPME sampling: application to urban plume in Verl, Germany. Environ. Sci. Technol. 45 (19), 8276-8282.

Limmer, M.A., Holmes, A.J., Burken, J.G., 2014. Phytomonitoring of chlorinated ethenes in trees: a four-year study of seasonal chemodynamics in planta. Environ. Sci. Technol. 48 (18), 10634-10640.

Loheide II, S.P., Butler Jr., J.J., Gorelick, S.M., 2005. Estimation of groundwater consumption by phreatophytes using diurnal water table fluctuations: a saturated-unsaturated flow assessment. Water Resour. Res. 41, W07030. https://doi.org/10. 1029/2005WR003942.

Martin, P., Brunke, M., 2012. Faunal typology of lowland springs in northern Germany. Freshwater Sci. 31 (2), 542-562. https://doi.org/10.1899/11-092.1.

Masset, O., Loew, S., 2010. Hydraulic conductivity distribution in crystalline rocks, derived from inflows to tunnels and galleries in the Central Alps, Switzerland.

Hydrogeol. J. 18, 863-891.

Massoli-Novelli, R., Petitta, M., 1997. Hydrogeological impact of the Gran Sasso tunnels (Abruzzi, Italy). In: Marinos, P.G., Koukis, G.C., Tsiambaos, G.C., Stournaras, G.C. (Eds.), Engineering Geology and the Environment 3. Balkema, Rotterdam, pp. 2787-2792.

Meinzer, O.E., 1923. Outline of Ground-water Hydrology, with Definitions. United States Geological Survey, Washington, D.C., pp. 71.

Meinzer, O.E., 1927. Large springs in the United States. United States Geological Survey, Washington, D.C., pp. 557.

Miller, M.P., Buto, S.G., Susong, D.D., Rumsey, C.A., 2016. The importance of base flow in sustaining surface water flow in the Upper Colorado River Basin. Water Resour. Res.

52, 3547-3562. https://doi.org/10.1002/2015WR017963.

Minckley, W.L., Deacon, J.E., 1991. Battle against Extinction: Native fish management in the American West. University of Arizona Press, Tucson.

Mott LaCroix, K.E., Tapia, E., Springer, A.E., 2017. Environmental flows in the desert rivers of the United States and Mexico: synthesis of available data and gap analysis. J. Arid Environ. 140, 67-78. https://doi.org/10.1016/j.jaridenv.2017.01.011.

Mueller, J.M., Lima, R.E., Springer, A.E., 2017. Can environmental attributes influence protected area designation? a case study valuing preferences for springs in Grand Canyon National Park. Land Use Policy 63, 196-205.

Nichols, W.D., 1994. Groundwater discharge by phreatophyte shrubs in the Great Basin as related to depth to groundwater. Water Resour. Res. 30 (12), 3265-3274.

Nippert, J.B., Butler Jr., J.J., Kluitenberg, G.J., Whittemore, D.O., Arnold, D., Spal, S.E., Ward, J.K., 2010. Patterns of Tamarix water use during a record drought. Oecologia 162, 283-292.

Obertegger, U., Borsato, A., Flaim, G., 2009. Rotifer-crustacean interactions in a pseudokarstic lake: influence of hydrology. Ecol. Aquat. https://doi.org/10.1007/ s10452-009-9285-0.

Odum, H.T., 1957. Trophic Structure and Productivity of Silver Springs, Florida. Ecol. Monogr. 27 (1), 55-112.

Oki, T., Kanae, S., 2006. Global hydrological cycles and world water resources. Science 313 (5790), 1068-1072

Pedley, H.M., 1990. Classification and environmental models of cool freshwater tufas. Sediment. Geol. 68, 143-154.

Pedley, M., 2009. Tufas and travertines of the Mediterranean region: a testing ground for freshwater carbonate concepts and developments. Sedimentology 56 (1), 221-246.

https://doi.org/10.1111/j.1365-3091.2008.01012.x.

Pentecost, A., 2005. Travertine. Springer, Berlin 445.

Petitta, M., Tallini, M., 2002. Groundwater hydrodinamic of the Gran Sasso Massif (Abruzzi): new hydrological, hydrogeological and hydrochemical surveys (1994-2001). Ital. J. Geosci. 121, 343-363.

Pfiester, L.A., 1976. Oocardium stratum a rare (?) desmid (Chlorophyceae). J. Phycol. 12, 134. https://doi.org/10.1111/j.1529-8817.1976.tb02841.x.

Poole, J., Bowles, D.E., 1999. Habitat characterization of Texas wild-rice (Zizania texana Hitchcock), an endangered aquatic macrophyte from the San Marcos River, Texas, USA. Aquat. Conserv. Mar. Freshwater Ecosyst. 9, 291. https://doi.org/10.1002/ (SICI)1099-0755(199905/06)9:3 < 291::AID-AQC349>3.0.CO;2-E.

Postel, S.L., 2000. Entering an era of water scarcity: the challenges ahead. Ecol. Appl. 10 (4), 941-948.

Postel, S.L., Daily, G.C., Ehrlich, P.R., 1996. Human appropriation of renewable fresh water. Science $271,785-788$.

Reiss, M., Chifflard, P., 2017. An opinion on spring habitats within the Earth's critical zone in headwater regions. Water 9, 645. https://doi.org/10.3390/w9090645.

Rockström, J., Falkenmark, M., Allan, T., Folke, C., Gordon, L., Jägerskog, A., Kummu, M., Lannerstad, M., Meybeck, M., Molden, D., Postel, S., Savenije, H., Svedin, U., Turton, A., Varis, O., 2014. The unfolding water drama in the Anthropocene: towards a resilience-based perspective on water for global sustainability. Ecohydrol. 7, 1249-1261.
Rodriguez-Iturbe, I., 2000. Ecohydrology: a hydrologic perspective of climate soil-vegetation dynamics. Water Resour. Res. 23, 349-357.

Rott, E., Hotzy, R., Cantonati, M., Sanders, D., 2012. Calcification types of Oocardium stratum Nägeli and microhabitat conditions in springs of the Alps. Freshwater Sci. 31, 610-624. https://doi.org/10.1899/11.084.1.

Schröder, H., Howein, H., Gerecke, R., 2006. Quelltypen und Quellfauna. Pages 214-220 in R. Gerecke and H. Franz (editors). Quellen im Nationalpark Berchtesgaden. Forschungsbericht 51. Nationalpark Berchtesgaden, Berchtesgaden, Germany. [in German].

Segadelli, S., Vescovi, P., Chelli, A., Petrella, E., De Nardo, M.T., Gargini, A., Celico, F., 2017a. Hydrogeological mapping of heterogeneous and multi-layered ophiolitic aquifers (Mountain Prinzera, northern Apennines, Italy). J. Maps 13 (2), 737-746. https://doi.org/10.1080/17445647.2017.1376228.

Segadelli, S., Vescovi, P., Ogata, K., Chelli, A., Zanini, A., Boschetti, T., Petrella, E., Toscani, L., Gargini, A., Celico, F., 2017b. A conceptual hydrogeological model of ophiolitic aquifers (serpentinised peridotite): The test example of Mt. Prinzera (Northern Italy). Hydrol. Process. 32, 969-1201. https://doi.org/10.1002/hyp. 11090.

Shannon, C.E., 1948. A mathematical theory of communication. Bell Syst. Tech. J. 27 (3), 379-423.

Sharaky, A.M., 2019. Ecohydrogeological challenges on Ethiopian water projects and their impacts on annual water share of Egypt: case study of Tekeze Dam. In: Negm, A.M. (Ed.), Conventional Water Resources and Agriculture in Egypt. Springer International Publishing, Cham, pp. 415-447.

Sinclair, D., 2018. Springs Geomorphology Influences Physical and Vegetation Ecosystem Characteristics in the Grand Canyon Ecoregion, Southwestern USA. MS Thesis. Northern Arizona University, Flagstaff.

Sorek, A., Atzmon, N., Dahan, O., Gerstl, Z., Kushisin, L., Laor, Y., Mingelgrin, U., Nasser, A., Ronen, D., Tsechansky, L., Weisbrod, N., Graber, E.R., 2008. "Phytoscreening": the use of trees for discovering subsurface contamination by VOCs. Environ. Sci. Technol. 42 (2), 536-542

Spence, G.H., Redfern, J., Aguilera, R., Bevan, T.G., Cosgrove, J.W., Couples, G.D., Daniel, J.-M., 2014. Advances in the study of fractured reservoirs. Geol. Soc. Lond. Spec. Publ. 374. https://doi.org/10.1144/SP374.9.

Spitale, D., Leira, M., Angeli, N., Cantonati, M., 2012. Environmental classification of springs of the Italian Alps and its consistency across multiple taxonomic groups. Freshwater Sci. 31 (2), 563-574.

Springer, A.E., Stevens, L.E., Anderson, D.E., Parnell, R.A., Kreamer, D.K., Levin, L, Flora, S.P., 2008. A comprehensive springs classification system: integrating geomorphic, hydrogeochemical, and ecological criteria. In: Stevens, L.E., Meretsky, V.J. (Eds.), Aridland Springs in North America: Ecology and Conservation. University of Arizona Press, Tucson, pp. 49-75.

Springer, A.E., Stevens, L.E., 2009. Spheres of discharge of springs. Hydrogeol. J. 17 (1), 83-93. https://doi.org/10.1007/s10040-008-0341-y.

Springs Stewardship Institute, 2019. Springs Online. Springs and Springs-Dependent Species Online Database (https://springsdata.org/)

Steinmann, P., 1915. Praktikum der Süßwasserbiologie. Teil 1: Die Organismen der fließenden Wassers. Bornträger, Berlin, Germany, pp. 184

Steube, C., Richter, S., Griebler, C., 2009. First attempts towards an integrative concept for the ecological assessment of groundwater ecosystems. Hydrogeol. J. 17, 23-35.

Stevens, L.E., Johnson, R.R., Estes C., The watershed continuum: a conceptual streamriparian ecosystem model, in Johnson, R.R., Carothers, S.W., Finch, D.M., Kingsley, K.J. Stanley, J.R.T. (Eds.), Riparian research and management: past, present, and future, Volume 2. U.S. Department of Agriculture, Forest Service, Rocky Mountain Research Station General Technical Report RMRS-GTR-303, Ft. Collins (in press).

Stevens, L.E., Schenk, E.R., Springer, A.E. Springs ecosystem classification. Ecological Applications (in press).

Stevens, L.E., Meretsky, V.J. (Eds.), 2008. Aridland Springs of North America: Ecology and Conservation. University of Arizona Press, Tucson.

Stevens, L.E., Ledbetter, J.D., Springer, A.E., Campbell, C., Misztal, L., Joyce, M., Hardwick, G., 2016. Arizona Springs Rehabilitation Handbook. Spring Stewardship Institute, Flagstaff, and Sky Island Alliance, Tucson, Arizona.

Struckhoff, G.C., Burken, J.G., Schumacher, J.G., 2005. Vapor-phase exchange of perchloroethene between soil and plants. Environ. Sci. Technol. 39 (6), 1563-1568.

Swistock, B., Sharpe, W., 2017. Springs development and protection. The Pennsylvania State University Extension Sevice. Availablve online at: https://extension.psu.edu/ spring-development-and-protection. Accessed 16 September 2019.

Taxböck, L., Linder, H.P., Cantonati, M., 2017. To what extent are Swiss springs refugial habitats for sensitive and endangered diatom taxa? Water 9, 967. https://doi.org/10. 3390/w9120967.

Thienemann, A., 1922. Hydrobiologische untersuchungen an quellen (I-IV). Archiv Hydoiol. 14, 151-190.

Tomaselli, M., Spitale, D., Petraglia, A., 2011. Phytosociological and ecological study of the springs in the Trento Province (Eastern Alps, Northern Italy). J. Limnol. 70, 23-53.

Tomlinson, M., Boulton, A.J., 2010. Ecology and management of subsurface groundwater dependent ecosystems in Australia a review. Mar. Freshw. Res. 61 (8), 936-949.

Trobej, M., Bednar, J.P., Waringer, J., Schagerl, M., 2017. Algal communities in springassociated limestone habitats of Austria. Aquat. Microb. Ecol. 80, 61-75.

Unmack, P.J., 2001. Biogeography of Australian freshwater fishes. J. Biogeogr. 28, 1053-1089.

US Forest Service, 2012. Groundwater-dependent ecosystems: Level II inventory field guide. U.S. Forest Service. General Technical Report WO-86b. U.S Department of Agriculture.

Ustin, S., Smith, M.O., Jacquemoud, S., Verstraete, M.M., Govaerts, Y., 1999. Geobotany: vegetation mapping for earth sciences remote sensing for the earth sciences, manual 
of remote sensing, third ed. John Wiley and Sons, pp. 189-248 Volume 3. van der Kamp, G., 1995. The hydrogeology of springs in relation to the biodiversity of spring fauna: a review. J. Kansas Entomol. Soc. 68 (2), 4-17.

Vincenzi, V., Gargini, A., Goldscheider, N., 2009. Using tracer tests and hydrological observations to evaluate effects of tunnel drainage in the Northern Apennines (Italy).

Hydrogeol. J. 17 (1), 135-150. https://doi.org/10.1007/s10040-008-0371-5. Vincenzi,

V., Gargini, A., Goldscheider, N., Piccinini, L., 2014. Differential hydrogeological effects of draining tunnels through the Northern Apennines, Italy. Rock Mech. Rock Eng. 47 (3), 947-965.

von Fumetti, S., Nagel, P., 2011. A first approach to a faunistic crenon typology based on functional feeding groups. In: Cantonati, M., Gerecke, R., Jüttner, I., Cox, E.J. (Guest Editors). Springs: neglected key habitats for biodiversity conservation. Journal of Limnology 70 (1s), 147-154. https://doi.org/10.4081/jlimnol.2011.s1.147.

Vörösmarty, C.J., McIntyre, P.B., Gessner, M.O., Dudgeon, D., Prusevich, A., Green, P., Glidden, S., Bunn, S.E., Sullivan, C.A., Reidy Liermann, C., Davies, P.M., 2010. Global threats to human water security and river biodiversity. Nature $467,555-561$

Vroblesky, D.A., 2008. User's Guide to the Collection and Analysis of Tree Cores to Assess the Distribution of Subsurface Volatile Organic Compounds. Scientific Investigations Report 2008-5088, U.S. Geological Survey, Reston, Virginia.

Vroblesky, D.A., Clinton, B.D., Vose, J.M., Casey, C.C., Harvey, G.J., Bradley, P.M., 2004. Ground water chlorinated ethenes in tree trunks: case studies, influence of recharge, and potential degradation mechanism. Ground Water Monit. Rem. 24 (3), 124-138. Wang,

X., Zhang, G., Jun, XuY., Shan, X., 2015. Defining an ecologically ideal shallow groundwater depth for regional sustainable management: conceptual development and case study on the Sanjiang Plain, Northeast China. Water 7 (7), 3997-4025.

Werum, M., Lange-Bertalot, H., 2004. Diatoms in springs from Central Europe and elsewhere under the influence of hydrogeology and anthropogenic impacts. In: In: Lange-Bertalot, H. (Ed.), Iconographia Diatomologica, vol. 13 A.R.G. Gantner, Ruggell, Liechtenstein.

White, W.N., 1932. A method of estimating ground-water supplies based on discharge by plants and evaporation from soil: Results of investigations in Escalante Valley, Utah, U.S. Geol. Surv. Water Suppl Pap., 659-A.

Wilcox, J.D., Johnson, K.M., 2016. Trichloroethylene (TCE) in tree cores to complement a subsurface investigation on residential property near a former electroplating facility. Environ. Monit. Assess. 188 (10), 587.

Williams, D.D., Danks, H.V., 1991. Arthropods of springs: Introduction. Memoirs Entomol. Soc. Canada 155, 3-4.

Wilson, J.L., Samaranayake, V.A., Limmer, M.A., Burken, J.G., 2018. Phytoforensics: Trees as bioindicators of potential indoor exposure via vapor intrusion. PLoS One 13 (2), e0193247. https://dol.org/10.1371/journal.pone.0193247.

Wolf, E., Gage, D., Cooper, D.J., 2006. Drosera rotundifolia L. (roundleaf sundew): A technical conservation assessment. USDA Forest Service, Rocky Mountain Region. http://fsweb.r2.fs.fed.us/rr/scp/plants/dicots/droserarotundifolia.pdf [accessed 4 Ap[ril 2019].

Yanosky, T.M., Hansen, B.P., Schening, M.R., 2001. Use of tree rings to investigate the onset of contamination of a shallow aquifer by chlorinated hydrocarbons. J. Contam. Hydrol. 50 (3), 159-173.

Yung, L., Lagron, J., Cazaux, D., Limmer, M., Chalot, M., 2017. Phytoscreening as an efficient tool to delineate chlorinated solvent sources at a chlor-alkali facility. Chemosphere 174, 82-89.

Zalewski, M., 2002. Ecohydrology - the use of ecological and hydrological processes for sustainable management of water resources. Hydrol. Sci. J. 47 (5), 825-834. Zalewski, M., Janauer, G.A., Jolankai, G. (Eds), 1997. Ecohydrology: a new paradigm for the sustainable use of aquatic resources. UNESCO, Paris (Technical Documents in Hydrology 7).

Zanini, A., Petrella, E., Sanangelantoni, A.M., Angelo, L., Ventosi, B., Viani, L., Rizzo, P., Remelli, S., Bartoli, M., Bolpagni, R., Chelli, A., Feo, A., Francese, R., Iacumin, P., Menta, C., Racchetti, E., Selmo, E.M., Giovanna Tanda, M., Ghirardi, M., Boggio, P., Pappalardo, F., De Nardo, M.T., Segadelli, S., Celico, F., 2018. Groundwater Characterization from an Ecological and Human Perspective: an Interdisciplinary Approach in the Functional Urban Area of Parma, Italy. Rendiconti Lincei. Scienze Fisiche e Naturali, pp. 1-16.

Zheng, X., Amesbury, M.J., Hope, G., Martin, L.F., Mooney, S.D., 2019. Testate amoebae as a hydrological proxy for reconstructing water-table depth in the mires of southeastem Australia. Ecol. Ind. 96 (1), 701-710. 